\title{
The impact of pre-analytical variables on measuring CSF biomarkers for Alzheimer's disease diagnosis: A review
}

Oskar Hansson a,b, ${ }^{*}$, Alvydas Mikulskisc ${ }^{c}$, Anne M. Fagan ${ }^{d}$, Charlotte Teunissene, Henrik Zetterberg f,g,h,i, Hugo Vanderstichelej, Jose Luis Molinuevo ${ }^{\mathrm{k}, \mathrm{t}}$, Leslie M Shaw', Manu Vandijck ${ }^{m}$, Marcel M. Verbeek ${ }^{n}$, Mary Savage ${ }^{\circ}$, Niklas Mattsson ${ }^{a}$, Piotr Lewczuk $^{p, q}$, Richard Batrlar, Sandra Rutz ${ }^{s}$, Robert A Deant, Kaj Blennow ${ }^{\text {h,i }}$

aDepartment of Neurology, Skåne University Hospital, Lund, Sweden

bMemory Clinic, Skåne University Hospital, Malmö, Sweden

'Biogen Inc, Boston, USA

${ }^{d}$ Department of Neurology, Washington University School of Medicine, St Louis, USA

eVU University Medical Center, Amsterdam, The Netherlands

fUK Dementia Research Institute, London, UK

gDepartment of Molecular Neuroscience, UCL Institute of Neurology, Queen Square, London, UK

${ }^{h}$ Clinical Neurochemistry Laboratory, Sahlgrenska University Hospital, Mölndal, Sweden

'Department of Psychiatry and Neurochemistry, the Sahlgrenska Academy at the University of Gothenburg, Mölndal, Sweden

jADx NeuroSciences, Gent, Belgium

kICN Clinic, Hospital Universitari, Barcelona, Spain

'Department of Pathology and Laboratory Medicine, Perelman School of Medicine, University of Pennsylvania, Philadelphia, USA

${ }^{m}$ Fujirebio-Europe NV, Gent, Belgium

${ }^{n}$ Radboud University Medical Center, Departments of Neurology and Laboratory Medicine, Donders Institute for Brain, Cognition and Behaviour, Nijmegen, The Netherlands

oMerck, Philadelphia, USA

${ }^{P}$ Department of Psychiatry and Psychotherapy, Universitätsklinikum Erlangen, and Friedrich-Alexander Universität Erlangen-Nürnberg, Germany

9Department of Neurodegeneration Diagnostics, Medical University of Bialystok, Poland

rRoche Diagnostics GmbH, Rotkreuz, Switzerland

This is the author's manuscript of the article published in final edited form as:

Hansson, O., Mikulskis, A., Fagan, A. M., Teunissen, C., Zetterberg, H., Vanderstichele, H., ... Blennow, K. (2018). The impact of preanalytical variables on measuring cerebrospinal fluid biomarkers for Alzheimer's disease diagnosis: A review. Alzheimer's \& Dementia, 14(10), 1313-1333. https://doi.org/10.1016/j.jalz.2018.05.008 


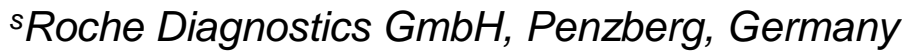

${ }^{t}$ Department of Pathology and Laboratory Medicine, Indiana University School of Medicine, Indianapolis, USA

"Corresponding author: Oskar Hansson, Memory Clinic, Skåne University Hospital, Lund 221 85, Sweden, oskar.hansson@med.lu.se, +46 313431791 


\section{Abstract}

INTRODUCTION:

Cerebrospinal fluid (CSF) biomarkers have the potential to improve the diagnostic accuracy of Alzheimer's disease. A lack of harmonized pre-analytical CSF-handling protocols accounts for a large proportion of observed variation and limits betweenstudy comparison of CSF biomarker concentrations.

\section{METHODS:}

This systematic review summarizes the current literature on the influence of different pre-analytical variables on CSF biomarker concentration. We evaluated the evidence for three core CSF biomarkers: $\beta$-Amyloid(1-42), total tau and phosphorylated tau.

\section{RESULTS:}

This review highlights where previous literature agrees on the influence of certain variables on CSF biomarkers, and where there is a lack of consensus, or little evidence available.

\section{DISCUSSION:}

A unified CSF handling protocol is recommended to reduce pre-analytical variability and facilitate comparison of CSF biomarkers across studies and laboratories.

Keywords: Cerebrospinal fluid; Biomarkers; Pre-analytical variables; Alzheimer's disease diagnosis; $\beta$-amyloid 42; Total tau; Phosphorylated tau 


\section{Research in context}

Systematic review: The PubMed and Cochrane databases were searched between 1995 and March 2017 with specific search terms to identify studies that analyzed the effect of pre-analytical variables on cerebrospinal fluid (CSF) biomarkers of Alzheimer's disease (AD). Relevant publications were identified, screened, and assessed. A total of 49 publications were analysed for the influence of pre-analytical variables and the results are discussed. We also summarize the variations between currently used CSF handling protocols.

Interpretation: This review highlights the consensus in the field on the influence of different pre-analytical variables. It also indicates where there is a lack of consensus or a need for further research.

Future directions: We recommend developing a unified CSF handling protocol; this could reduce the impact of pre-analytical variables on biomarker measurement. This in turn could improve the diagnostic accuracy for $A D$ and enhance clinical trial recruitment.

\section{Highlights}

- CSF biomarkers of Alzheimer's disease are influenced by pre-analytical variables.

- Inconsistencies in published evidence on each variable's effect.

- A unified protocol may reduce CSF biomarker variability and improve diagnosis. 


\section{Introduction}

Alzheimer's disease $(A D)$ is thought to be a continuum with three main stages: preclinical (cognitively unimpaired), prodromal (with mild cognitive symptoms), and dementia (more advanced clinical symptoms) [1]. Disease-modifying treatments in development targeted at $A D$ will likely have greatest clinical benefit early in the $A D$ continuum, before neuronal damage is widespread $[2,3]$. It is challenging to definitively diagnose early $A D$ using clinical criteria alone [1]; however, biomarkers can detect changes in underlying neuropathology when only mild cognitive symptoms are present [4-7], or even at preclinical stages [8-12].

\subsection{The potential impact of biomarkers in AD diagnosis and research}

A biomarker is an objective measure of a biological or pathological process that can be used to monitor normal physiological processes, or evaluate disease risk or prognosis, to guide clinical diagnosis or to monitor therapeutic interventions [13]. Several physiological changes related to the pathogenesis of AD (such as neuritic plaques, tangles, and synapse loss) have been well documented. These are accompanied by changes in the levels of some molecules, both in the brain and cerebrospinal fluid (CSF), several of which have been suggested as potential biomarkers in the field of $A D$ for specific applications (e.g., diagnosis, treatment follow-up) [14].

Patients with AD have a characteristic profile of altered concentrations of three CSF protein biomarkers: $\beta$-Amyloid $(A \beta)(1-42)$, total tau (tTau), and phosphorylated tau (pTau) [15-17]. While these biomarkers may be individually affected by non-ADrelated pathologies, for example $A \beta(1-42)$ in subcortical vascular dementia [18], the combination of the three core biomarker changes is known as the AD 'signature' or 'profile' [4,5,19-22]. 
$A \beta(1-42)$ is the main component of amyloid plaques associated with $A D$ [23-25].

Currently, the only FDA-approved method to detect $A \beta$ deposits within the brain is $\beta$ amyloid positron emission tomography (PET) [26]. However, several commercially available assays for measuring $A \beta(1-42)$ (and other core AD biomarkers) in CSF are approved for diagnostic use in the European Union [27-29]. In addition, 10\% of cognitively normal elderly individuals have biomarker evidence of amyloidosis but no cognitive symptoms [30]. Low CSF $A \beta(1-42)$ could be an early indicator of preclinical AD before amyloid deposition rises to levels visible by PET imaging [31].

Brain amyloid pathology is correlated with abnormally low levels of $A \beta(1-42)$ in the CSF $[2,32-36]$. There is high concordance of CSF $A \beta(1-42)$ with $\beta$-amyloid PET status in both AD dementia and prodromal AD [4]. Concordance is further improved by using the ratio of CSF $A \beta(1-42) /(1-40)$, CSF $p T a u / A \beta(1-42)$ or CSF tTau/A $\beta(1-$ 42) $[16,18,37-40]$. Altered levels in the concentration ratio of CSF $A \beta(1-42)$ and $A \beta(1-40)$ are observed in subjects influenced by the apolipoprotein $E(A P O E) \varepsilon 4$ allele [41], a strong genetic risk factor for $A D$ [42].

CSF tTau is increased following neuronal injury or degeneration and is associated with cognitive decline $[43,44]$. An increase in CSF tTau concentration is characteristic of neurodegenerative disorders such as AD [45], but is also found in acute neuronal injury, for example, ischaemic stroke [46], other tauopathies (e.g., corticobasal syndrome [47]), and very high concentrations are found in disorders with rapid neuronal degeneration, for example Creutzfeldt-Jakob disease (CJD) [48]. Hyperphosphorylated tau is an important component of neurofibrillary tangles, which are a pathologic hallmark of $A D[2,14,49]$. High CSF pTau correlated with cortical tangle pathology in some studies [50,51], with the exception of Engelborghs, et al. 
(2007) [52], while high levels of CSF pTau were found in AD patients (up to 3.4-fold higher than healthy controls) [53]. Studies have found that CSF pTau181P correlated with the amount of cortical amyloid measured via PET imaging [16] or CSF A $\beta(1-$ $42) /(1-40)$ ratio [41]. The inclusion of pTau as a biomarker for AD together with $A \beta(1-42)$ and tTau can help differentiate $A D$ from normal ageing and difficult diagnoses (e.g., Parkinson's disease, CJD, some forms of non-AD dementia), and improve diagnostic performance $[54,55]$. CSF pTau 181 P concentration was found to be the most statistically significant single variable of the three for discrimination between AD and dementia with Lewy bodies in one study [54]. While pTau ${ }_{181 \mathrm{P}}$ is the most studied form, different phosphorylated epitopes, detected using different antibody combinations, may also result in a better separation of $A D$ from non-AD dementia [56,57].

Research guidelines from the National Institute on Aging and the Alzheimer's Association (NIA-AA; [58,59]) and International Working Group (IWG-2; [60]) recommend including core biomarkers in $A D$ diagnostic assessment, while the European Academy of Neurology recommends CSF biomarker assessment to aid AD differentiation [61]. As well as having diagnostic potential, changes in the core AD biomarkers precede cognitive changes and predict clinical progression in patients with mild cognitive impairment $(\mathrm{MCl})[5,7,17,62,63]$, and effectively stratify patients for their risk of developing AD dementia [5,7,20,21,39,64]. Promisingly, these biomarkers also detect pathological changes associated with preclinical AD in cognitively healthy elderly individuals $[12,40,65,66]$, and can enhance both differential diagnosis and prognostic stratification within AD populations.

Accurate, consistent, and reliable biomarker measurement remains a goal for researchers and clinicians alike, but requires consensus to establish universal cut-off 
values. However, the significant variability documented in CSF biomarker measurements across research and clinical studies [2,67-69] has hampered these efforts. The translation of cut-off values between clinical sites and studies has been investigated $[64,70]$ but can lead to patient misclassification, which in turn could influence clinical decision-making or clinical trial eligibility.

\subsection{Variables affecting CSF biomarker concentration}

CSF biomarker concentration can be affected by clinical, analytical, and preanalytical variables [71-73]. Clinical variables (besides AD and non-AD pathology) include age and $A P O E$ genotype [30]. Analytical procedures are related to the assay itself, for example, differences in technician skills and training, operating procedures, assay manufacturing or batch-to-batch variations in kits [74]. Considerable work has been done to standardize CSF biomarker measurement across different assays and laboratories. Notable efforts include: 1) the development of certified reference materials for the CSF biomarkers, currently underway within the International Federation of Clinical Chemistry Working Group for CSF proteins [75], 2) the introduction of reference measurement procedures (RMPs) based on liquid chromatography tandem mass spectrometry for CSF $A \beta(1-42)$ quantification, which were recently formally certified by the Joint Committee for Traceability in Laboratory Medicine (C11RMP9 and C12RMP1, respectively) [76,77], and 3) the establishment of quality control programs for monitoring between-laboratory and between-batch variability of commercially available immunoassays [28,72,78-82].

Pre-analytical variables include CSF sampling materials and methodology, CSF handling, and storage procedures (see $[71,80]$ for reviews). Following notable improvements in analytical methods, recent studies have revealed that pre-analytical factors account for a considerable proportion of the total variability observed in 
biomarker concentrations $[71,83]$. Thus, there is a growing view that standardization of selected pre-analytical factors might well significantly reduce this variability, improve biomarker diagnostic accuracy and encourage greater inclusion of CSF biomarker testing in both clinical research and routine clinical practice.

\subsection{Rationale for this systematic review}

Standardization of key analytical issues is increasingly being embraced by the AD community. In contrast, clinics and diagnostic laboratories have commonly developed their own site-specific protocols for the pre-analytical handling of CSF $[14,80]$. While some centres have published their protocols, the majority follow a small number of published protocols or recommendations, while a variety of adjustments to these protocols also have been published $[35,71,80,84-87]$. In addition, many unpublished adjustments to pre-analytical protocols have been adopted (Fagan A, personal observation). Where differences in pre-analytical procedures exist, direct comparison of CSF biomarker data between groups is difficult or biased, albeit possible [88]. As new studies are published, there is a need to update protocols and work towards their subsequent global implementation.

\section{2. $\operatorname{Aim}$}

This review has two aims: 1) to compare current pre-analytical recommendations and protocols for handling CSF samples prior to measurements of the core $A D$ biomarkers of $A \beta(1-42)$, pTau and tTau and 2) to summarize the effects of preanalytical variables on core AD CSF biomarker concentration based on a systematic literature review. 


\section{Methods}

In accordance with PRISMA guidelines, we conducted a systematic review of the PubMed (comprising citations from MEDLINE, life science journals and online books) and Cochrane Library databases from 1995 to March 2017 with five sets of search terms to identify studies that analyzed the effect of pre-analytical variables on $A D$ CSF biomarkers. In addition, we examined reference lists of reviews and selected original research articles for relevant studies; the authors also suggested additional relevant publications. The PubMed search strategy was designed to select studies with pre-analytical variables of $A \beta(1-42)$, pTau, or tTau concentration in CSF (Appendix A). Duplicates within searches were removed by a reviewer and abstracts were screened using predefined criteria:

- eligible studies described AD CSF biomarker measurements when one or more pre-analytical variable(s) were investigated

- studies were excluded if 1) they did not collect and analyze CSF, 2) did not specifically include or mention $A \beta(1-42)$, pTau or tTau, 3) steps investigated referred to analytical rather than pre-analytical variables, 4) were not in English, 5) were not based on humans, 6) were conference abstracts only, or 7) were review articles.

Studies examining the effect of pre-analytical variables were evaluated and evidence that a variable had no effect, or altered concentration, was extracted and summarized. 


\section{Results}

\subsection{Comparison of pre-analytical protocols for CSF measurements of core AD}

biomarkers

We identified six pre-analytical protocols used in multicentre, international studies including AD biomarker measurements (Table 1). Several steps were different and these steps were compared in Table 1. Only the recommended location of sampling (LP) and storage temperature was the same in all protocols examined. In contrast, recommendations for LP needle size, collection volume, and centrifugation steps varied.

\subsection{Summary of pre-analytical variable effects on CSF measurements of core} $\mathrm{AD}$ biomarkers

The systematic review identified 593 articles; 211 duplicates were removed and 49 studies were assessed (Fig. 1). The evidence for the influence of CSF sampling procedure (Table 2), CSF storage conditions (Table 3) and CSF treatment conditions (Table 4) on core AD biomarker concentration (see Fig. 2) are discussed in more detail below.

\subsubsection{The influence of sampling procedure on CSF biomarker concentration}

Several variables within the process of taking CSF samples from individuals could affect biomarker concentration. These include the conditions immediately prior and during the sampling procedure, for example, the timing, method (e.g., needle type) and the technique used. 


\subsubsection{Timing of CSF sampling}

Most current protocols recommend a time window to draw CSF for $A \beta(1-42)$ measurements (Table 1). Despite this recommendation, not all studies assessed describe significant differences in CSF biomarker concentration across a 24-hour period $[89,90]$. There were several reports of significant changes in CSF A $\beta(1-42)$ concentration over a number of hours (Table 2). CSF samples collected hourly in 15 healthy individuals revealed a significant (up to 4-fold) change in $A \beta(1-42)$ levels, with increasing concentrations over 36 hours [91]. Huang, et al. (2012) also described a longitudinal linear rise in CSF $A \beta(1-42)$ concentration over 36 hours in young (18-60 years old) control individuals, in addition to a circadian-like sinusoidal pattern. The amplitude of diurnal change in CSF $A \beta(1-42)$ concentration decreased with age, while hourly dynamics and linear rise were attenuated in individuals with known amyloid deposition [92]. A recent report using pooled data from several sites also found significant diurnal variation in $A \beta(1-42)$ levels [93], with a gradual increase in concentration in the first 12 hours (up to 200\% higher from initial baseline draw), which did not return to baseline levels after 24 hours. Samples from indwelling catheters used in this study derived from individuals who participated in clinical research studies and were given placebo treatment [93]. This study comprised the highest sample number examining this variable to date $(n=178)$. All other studies examined had relatively small sample sizes $(n=10-15)$.

It is notable that, in these studies, CSF was repeatedly sampled via indwelling lumbar sac catheterization. Therefore, the frequency of CSF sampling and aspects of the procedural technique may have influenced the interpretation of diurnal variation. All groups employing this approach noted a steady increase in CSF A $\beta$ levels over the first few hours. Materials in the catheter (e.g., the presence of a 
bacterial filter), sampling frequency and the volume of CSF being withdrawn (especially nearer the first part of the sampling period) may have influenced the results of studies investigating CSF concentration changes over short periods of time [93-96]. Moreover, the initial sampling may leave a hole in the dura mater allowing CSF to leak in to the surrounding tissues; this could change the CSF circulation dynamics, thereby altering CSF $A \beta(1-42)$ concentration.

The limited data available on diurnal variability of CSF tTau or pTau did not generally reveal any significant diurnal change for tTau $[89,90]$, with a linear increase that was reported by Slats, et al. (2012) attributed to a methodological artefact [95]. This same study was the only one to report a steady increase in pTau and a circadian-like fluctuation (over 24 hours using a cosinor fit, a fluctuation of $2.5 \mathrm{pg} / \mathrm{mL}$ for individuals with $\mathrm{AD}$ and $1.4 \mathrm{pg} / \mathrm{mL}$ for the control group was seen, $\mathrm{n}=6, P<.005)$ [95].

In summary, the evidence for diurnal variability of CSF $A \beta(1-42)$ and pTau concentration is inconclusive. However, differences in observed diurnal variability of CSF $A \beta(1-42)$ between studies may be dependent on CSF sampling procedure (e.g., catheterization), age and/or, the presence of amyloid pathology. More accurate assays with increased sensitivity in future may aid the resolution of this open question. In addition, it would be useful to compare CSF collected at different time points in the same individuals over several weeks.

\subsubsection{Location and volume of CSF sampling}

CSF can be sampled from the lumbar region of the spine or the cerebral ventricles/cisternae via a shunt. AD biomarker protocols universally recommended sampling to be performed by LP at the level of L3/4 or L4/L5, i.e., a level safely below the spinal cord (supported by recent consensus guidelines [97]) (Table 1). 
Collection volumes in these protocols vary from $\geq 1.5 \mathrm{~mL}$ to $20 \mathrm{~mL}$ (Table 1). CSF biomarkers for other neurodegenerative disease (e.g., $\alpha$-synuclein as a biomarker in Parkinson's disease) may vary along the rostro-caudal gradient $[98,99]$. If large volumes of CSF are obtained via the lumbar sac, CSF will be in effect drawn from more rostral reaches of the spinal canal and so any rostro-caudal gradient in biomarker concentration would have implications for interpreting results. However, we found limited evidence in the literature that CSF AD biomarker concentrations are gradient dependent. No significant change in the concentration of CSF $A \beta(1-42)$ was observed along the rostro-caudal gradient, when analyzing concentrations in different portions of large CSF volume samples $[73,100]$. This included a comparison of CSF biomarker concentration between four successive $10 \mathrm{~mL}$ volumes [73]. Volumes larger than $50 \mathrm{~mL}$ may lead to a slight increase in $A \beta(1-42)$ concentration (though this effect is below $5-10 \%$ [Hansson O, unpublished observation]); however, such excessive volumes are not relevant in most clinical settings.

The majority of studies examined in this review also found no significant difference between CSF $A \beta(1-42)$ concentration from lumbar or ventricular locations $[90,101,102]$. However, a study of 15 patients with normal pressure hydrocephalus $(\mathrm{NPH})$ reported higher concentration of CSF $A \beta(1-42)$ from lumbar versus ventricular catheter samples [103]. Conversely, higher pTau concentrations were noted in ventricular versus lumbar CSF from patients with $\mathrm{NPH}$, in agreement with Djukic, et al. [102]. Similar findings were observed for tTau $[90,103]$.

Available evidence indicates that there is no significant rostro-caudal effect on CSF $A \beta(1-42)$ concentrations with the volumes of CSF collected routinely for biomarker samples. Further evidence may be required to determine rostro-caudal gradient 
changes in tTau and pTau in control populations. The rostro-caudal gradient of the AD biomarkers may also depend on the patient's underlying medical conditions.

\subsubsection{Type of puncture needle}

In this review, we did not identify any studies directly comparing the effect of needle type on CSF AD biomarkers, probably due to the technical difficulties in varying this factor objectively. However, current protocols all recommend an atraumatic (pen-

point) needle, although with different sized gauges (22, 24 or 25 G; Table 1). A study found that conventional needles (compared with atraumatic ones) led to minor serum protein contamination of CSF [104], though this may not affect AD CSF biomarker concentrations (see section 4.2.6).

As we have found no evidence of an effect of puncture needle on core AD CSF biomarker concentration, the current protocol recommendations of needle type may relate more to prevention of patient side effects. For example, in multicentre studies, atraumatic needles prevented post-LP complaints such as back pain and headache. A larger needle diameter was associated with severe headache [105], whereas smaller 24 gauge Sprotte needles were associated with a low incidence of post-LP headache [106].

\subsubsection{Collection method}

Most current protocols do not specify a drainage method, though the Alzheimer's Disease Neuroimaging Initiative (ADNI) and BioFINDER protocols recommend gravity drip to allow CSF to flow freely (Table 1). It is well recognized that different tube materials can significantly affect CSF AD biomarker concentration (see below), which led to a suggestion that aspirating CSF in plastic syringes could cause a significant decrease in $A \beta(1-42)$ concentration compared with gravity drip. 
Conversely, use of a syringe could enable faster collections and direct aliquoting, which could help minimize CSF $A \beta(1-42)$ loss through adsorption. A direct comparison of the two methods in a cohort of 54 study participants (38 healthy controls, eight with $\mathrm{MCl}$ and eight with $\mathrm{AD}$ ) found no significant differences in CSF $A \beta(1-42), p T a u$, or tTau concentration [107]. In this study, aspiration samples were taken following sequential gravity drip samples, and so could retain possible gradient effects on concentration.

CSF may also be collected through a catheter (first used to measure the CSF pressure), and a comparison of two catheter types found no difference in CSF AB(142) concentration [73]. Another study found that manometer use significantly reduced (by 4-6\%) CSF $A \beta(1-38), A \beta(1-40)$ and $A \beta(1-42)$ concentrations [108]. As mentioned, this may be a result of tube or pipette material adsorption (see section 4.2.1). Overall, there are few studies that have directly compared drainage methods and no conclusive evidence of an effect of collection method on core CSF AD biomarker concentration has been reported. It would be very challenging to directly compare this parameter in more detail without potential confounders.

\subsubsection{Blood contamination}

Blood contamination of CSF from tissue trauma has been reported to occur in $\sim 15 \%$ of LPs [109], but is most often minor (Blennow K, personal observation). Proteins, including albumin and proteases present in blood, may bind or degrade $A \beta(1-42)$, $[110,111]$, while blood cells themselves contain significant amounts of $A \beta(1-42)$ [112]. Many of these proteins are naturally occurring in the CSF and may be even more abundant if the blood-CSF barrier is impaired (e.g., with acute meningitis) or when the CSF samples are contaminated with blood during the collection process. Accordingly, CSF collection protocols consistently recommend discarding the initial 
1-2 $\mathrm{mL}$ of CSF if blood contamination is noted based on visual assessment, or if the CSF sample contains $>50$ erythrocytes per $\mu \mathrm{L}$ (Table 1). However, there is conflicting evidence on whether plasma proteins can affect biomarker concentration. For example, two studies found no significant effect of the addition of albumin at the time of sample incubation [113] or minimal blood contamination [73] on $A \beta(1-42)$ concentration. Conversely, CSF A $\beta(1-42)$ concentration in samples spiked with plasma (corresponding to a CSF/serum albumin ratio of 55; Table 2) was significantly reduced up to $49 \%$ [73]. It should be noted that CSF/serum albumin ratios in this range are not found in $A D$ cases or other chronic neurodegenerative disorders. The opposite effect was seen by Leitao, et al. (2015), who spiked samples with 5000 erythrocytes $/ \mu \mathrm{L}$ and found a small but significant increase in both CSF $A \beta(1-42)$ and pTau concentration (6 and 11\%, respectively) [114]. Experimental design may therefore explain some of these conflicting results. Red blood cell contamination may be more critical for the concentration of biomarkers for other neurological conditions, such as Parkinson's disease, than the core AD biomarkers $[115,116]$

Taken together, these studies suggest that blood contamination may affect core AD biomarker concentration and that grossly contaminated samples should be discarded. However, further research may be needed to determine acceptable contamination levels.

\subsection{The influence of CSF storage on biomarker concentration}

The steps between performing a LP and measuring CSF biomarker concentration may introduce variability. These include the types and size of pipettes and tubes for transferring and processing samples, the CSF volume-to-surface ratio, and the temperature at which samples are held. 


\subsubsection{Tube material}

Many published studies examined tube material and the majority showed that different tubes adsorb CSF biomarkers to varying degrees. CSF samples are often exposed to many tubes, not only collection and storage tubes, but also those used for pooling CSF for certain purposes. Of the three CSF AD biomarkers examined in this review, $A \beta(1-42)$ concentration was affected to the greatest extent, likely due to the hydrophobic nature of the peptide.

The change in CSF biomarker concentration caused by the tube material, or 'tube effect', was shown to happen quickly ( $<5$ minutes) and was not further affected by long incubation time (up to 48 hours, at $2-8^{\circ} \mathrm{C}$ [117]). The 'tube effect' on CSF $A \beta(1-$ 42) concentration loss was greater when the initial CSF $A \beta(1-42)$ concentration was higher (>1000 pg/mL compared with 400-500 pg/mL [83]).

Standard protocols recommend polypropylene (PP) as a tube material (Table 1); indeed, polystyrene and glass tubes significantly reduced CSF $A \beta(1-42)$ concentration $[73,118,119]$. However, recent groups have shown that the type of PP - as homo or copolymers - or with additives such as polyethylene copolymers, also significantly altered CSF $A \beta(1-42)$ concentration [117,120-122]. For example, variation of up to $48 \%$ was observed among 11 tubes all listed by their manufacturer as PP [117].

Tubes treated to be 'low binding' (LOB) were found to yield significantly greater CSF $A \beta(1-42)$ concentration compared with untreated PP tubes [123,124]. Moreover, the chemical composition of the tube could influence the effects of freezing and tube volume on CSF A $(1-42)$ concentration; for example, an additional freeze/thaw cycle 
reduced CSF $A \beta(1-42)$ concentration by $>25 \%$ in a PP tube, but had almost no effect when LoB storage tubes were used [124].

CSF $A \beta(1-42)$ adsorption onto tube surfaces will occur with each transfer to a new tube $[83,124,125]$. Reduced recovery of measurable CSF $A \beta(1-42)$ can result from adsorption to transfer pipettes, in addition to collection or storage tubes [83]. In one study, transfer of CSF samples from LoB tubes to PP tubes decreased $A \beta(1-42)$ concentration by $42.5 \%$. This is significant since a recent survey across four academic AD diagnostic reference centres found that $0-2$ transfers of CSF occur on average (occasionally more) [83].

Different tube types have been shown to influence CSF pTau and tTau concentration, but within the range of acceptable assay variation $( \pm 8 \%,[117])$. Although one study found that CSF tau concentration was not affected by adsorption when transferred between different brands of tubes [83] another recent study did find transfer to a PP tube caused a significant decrease in CSF tTau [126], while a reduction was also reported for transfers to polystyrene tubes [119].

In summary, the evidence indicates that CSF $A \beta(1-42)$ concentration is significantly affected by tube type, while CSF pTau and tTau concentration is not notably affected. Peptide ratios can be more consistent than single peptide concentrations as they are not altered as much by interactions of single peptides with tube material [119]. Interestingly, it has been shown that using $A \beta(1-42) /(1-40)$ ratios $[83,119]$, but not $A \beta(1-42) /$ tau [126], can reliably compensate for tube-based variation in $A \beta(1-42)$ concentration. 


\subsubsection{Aliquot tube volume}

Current protocol recommendations for both tube volume (between $0.1-0.75 \mathrm{~mL}$ ) and the CSF fill volume (either no specification, or between 50 and $>75 \%$ full) vary considerably (Table 1).

The CSF surface to tube volume ratio can affect CSF $A \beta(1-42)$ concentration; there is a consensus in the literature that a larger ratio results in lower CSF $A \beta(1-42)$ concentration (Table 3; $[83,114,124,127])$. For example, one study observed that a loss in CSF $A \beta(1-42)$ concentration following tube transfer depended on starting volume, with higher surface area to volume ratios increasing $A \beta(1-42)$ adsorption [83]. In contrast, there is limited evidence of an effect of tube volume on CSF tTau concentration, although a decrease in concentration with decreased volume, dependent on tube material, was reported for tTau [124] and a weak association also noted [127]. We found no reports of an effect of tube volume on the concentration of pTau. Current evidence supports limiting the surface area to volume ratio when using samples for CSF $A \beta(1-42)$ concentration, but specifics vary, warranting further investigation.

\subsubsection{Temperature between collection and analysis/storage}

There are several differences in the recommended time that CSF samples can be left at room temperature (RT) or cooled (Table 1). Many studies have investigated the stability of CSF biomarkers at different temperatures, with emphasis on the length of time samples were left at RT immediately following LP as a practical consideration in the clinical setting (Table 3).

Several studies that started with fresh samples agreed that storing CSF at RT for up to 24 hours had no significant effect on CSF $A \beta(1-42)$ concentration $[73,100,128]$. 
Measurements on samples left at RT for longer than 24 hours have been more variable, with studies reporting increasing $[100,129]$ or decreasing [130] CSF A $\beta(1-$ 42) concentration, or no effect [131-133]. Hypotheses for the increase or decrease include $A \beta(1-42)$ release from amyloid-binding proteins [100], increased $A \beta(1-42)$ adsorption to tube material [83], or proteolytic degradation [129].

In comparison with CSF $A \beta(1-42)$, studies report no changes in CSF pTau or tTau concentration over short timeframes when kept at RT [128,129,131,134]. A decrease in tTau protein at $37^{\circ} \mathrm{C}$ or $\mathrm{RT}$ has been reported after $\sim 12$ days, though this was not seen in samples kept at $4^{\circ} \mathrm{C}[130,132]$.

A few studies have assessed the influence of different cooling methods or freezer temperatures, with limited evidence that colder temperature may limit biomarker concentration loss. For example, snap freezing samples in liquid $\mathrm{N}_{2}$ increased CSF $\mathrm{A} \beta(1-42)$ concentration compared with freezing in a $-80^{\circ} \mathrm{C}$ freezer $(P=.048)$, but may not be practical in the clinic setting. In addition, freezing at $-80^{\circ} \mathrm{C}$ yielded a higher CSF pTau concentration than freezing at $-20^{\circ} \mathrm{C}(P=.001)[100]$.

Most evidence for CSF $A \beta(1-42)$ concentration supports limiting the time at RT to less than 24 hours, followed by analysis or freezing. However, a comparison using newer fully automated assays with fresh CSF stored for various times compared with samples frozen at $-20^{\circ} \mathrm{C}$ or $-80^{\circ} \mathrm{C}$ for the same period is warranted. Although no evidence of significant temperature effect was found for tTau and pTau, freezing method and temperature effects on tau concentrations also merits further study.

\subsubsection{Freeze/thaw cycles}

Evidence on the effects of freeze/thaw cycles on biomarker concentration is inconsistent; however, up to three cycles was the standard recommendation in 
current protocols (Table 1). Following many reports on freezing effects on CSF biomarker concentration, most studies have shown that multiple freeze/thaw cycles decrease CSF biomarker concentration. The majority of studies found no significant effect of one freeze/thaw cycle on the CSF concentration of $A \beta(1-42)$, pTau or tTau, compared with fresh samples (Table 3), or on mass spectra intensities [135]. One notable exception was a multicentre analysis that suggested frozen samples had higher diagnostic accuracy than fresh samples for CSF tTau and A $\beta(1-42)$ concentration [29], although this has not been confirmed.

Significant reductions or unsystematic changes in CSF $A \beta(1-42)$ concentration have been described after strict application of two $[113,120]$, three $[130,131,136]$, four [100] or five [114] cycles of freeze/thawing. A freeze/thaw-dependent decrease in CSF A $\beta(1-42)$ concentration may be more pronounced at lower initial concentrations of CSF A $\beta(1-42)$ [113].

For CSF pTau and tTau, similar disagreement exists regarding the number of freeze/thaw cycles that are possible before concentration is significantly reduced. For example, no group has described a significant change in concentration from one freeze/thaw cycle, though a significant reduction was seen in CSF tTau concentration after two [100] or three [131,132] cycles. Conversely, Leitao, et al. (2015) found up to at least five freeze/thaw cycles had no significant effect on CSF tTau or pTau concentration.

In summary, studies agreed that increasing the number of freeze/thaw cycles decreases CSF concentration of $A \beta(1-42)$, tTau and pTau, but evidence on the exact number of cycles is inconclusive. A note of caution is recommended when assessing this variable, however; the influence of freeze/thaw cycles reported here 
may not be purely a result of the temperature change, but rather due to the pipetting and tube transfer steps or a change in surface area/volume ratio increasing adsorption to these materials.

\subsubsection{Storage duration}

Current protocols do not specify a time limit on long-term storage at $-80^{\circ} \mathrm{C}$, except the $<2$ years recommended in the BIOMARKAPD protocol [80] (Table 1).

Investigations have consistently shown that CSF biomarkers $(A \beta(1-42)$, pTau and tTau) are reasonably stable over time, when stored at $-80^{\circ} \mathrm{C}$ (Table 3;

$[73,123,130,131,133,134,137-140]) ;$ a recent study found that, if using a single batch of assays following varying sample storage times, storage for up to 12 years had no significant effect [140]. Only one report was found in this review that deviated from this, describing an increase in concentration of some samples following 7 months [138]. However, it should also be noted that lot-to-lot variability or assay storage may have an influence when comparing CSF concentration changes analyzed on different occasions over time [140].

In general, the literature is in agreement that storage at $-80^{\circ} \mathrm{C}$ for up to 6 months has little or no effect on CSF Aß(1-42), pTau181P, and tTau concentration.

\subsection{The influence of CSF treatment on biomarker concentration}

The treatment of CSF prior to biomarker assessment can affect biomarker concentration. This includes additives, heat treatment, centrifugation, and/or mixing of samples.

\subsubsection{Additives}

Additives are not recommended by current diagnostic protocols (Table 1). Additives such as mild detergents (Triton-X 100 or Tween-20) can alter protein binding, and 
several studies have shown that CSF samples that have been treated with $0.05 \%$ Tween-20 have higher CSF A $\beta(1-42)$ concentration (Table 4). For example, $0.1 \%$ Tween-20 or $0.05 \%$ TritonX-100 both increased CSF A $\beta(1-42)$ concentration by 75\% in individuals with AD [73], although Willemse, et al. (2017) found that the addition of Tween-20 did not improve the discrimination of AD patients from control subjects [83].

The detergent possibly interferes with binding of CSF $A \beta(1-42)$ to tube material $[122,127]$, and therefore could be a way of mitigating adsorption [123].

Subsequently, the standard strong correlation between tube surface area and increased CSF $A \beta(1-42)$ concentration, probably reflecting $A \beta(1-42)$ adsorption, is not present in samples containing $0.05 \%$ Tween-20 [127]. Even a pre-wash step of tubes with detergent-containing buffers was enough to considerably reduce CSF $A \beta(1-42)$ tube adsorption (optimal dose recovery was $0.01 \%$ Tween-20) [124]. To prevent $A \beta(1-42)$ loss in earlier steps in pipette tips or tubes prior to transfer, detergent could be added at the time of CSF withdrawal [83].

Detergents or other additives could affect the concentration and detection of other analytes used as biomarkers and modify the equilibrium between protein-bound and free analytes in CSF, or the ratio of $A \beta$ isoforms, and so should be used with caution [124]. In addition, detergents could affect reagent antibodies in immunoassays. Despite this, $0.05 \%$ detergent (Triton-X 100 or Tween-20) did not seem to affect sensitivity, specificity, diagnostic accuracy [141] or intra-assay variability for CSF $A \beta(1-42)$ concentration [124]. Some authors do explicitly recommend detergent use to mitigate CSF $A \beta(1-42)$ adsorption [123,127], for example, for older samples stored in high absorption tubes. 
In summary, there is evidence that $0.05 \%$ Tween-20 may help mitigate CSF $A \beta(1-$ 42) adsorption onto tubes and boost concentration $[124,127,141,142]$. Though there is limited evidence that $0.05 \%$ detergent has any effect on CSF tTau or pTau $[141,142]$, unknown effects on potential interactions of additives with other proteins and assay reagents understandably restricts any recommendation for their use. It should also be noted that the certified reference material for $A \beta(1-42)$ is composed of neat CSF without additive, calibrated against mass spectrometry methods [75]. It would be interesting to directly compare CSF $A \beta(1-42)$ concentration between the lowest binding tubes on the market with and without the addition of $0.05 \%$ Tween-20 to quantify potential loss in more detail.

\subsubsection{Heat denaturation}

Current protocols do not recommend heat denaturation as a protocol step prior to CSF biomarker measurement (Table 1). Nevertheless, the possible effect of this step on CSF $A \beta(1-42)$ concentration has been sporadically investigated (Table 4). In 2000, Vanderstichele et al demonstrated that boiling CSF samples had no effect on CSF $A \beta(1-42)$ concentration [113]. In contrast, heat denaturation was recently reported to increase CSF $A \beta(1-42)$ concentration (15 mins at $100^{\circ} \mathrm{C}$ increased levels by $42-71 \%)$, and this increase was hypothesized to be due to detection of $A \beta(1-42)$ that was previously bound in protein complexes or masked by epitopes [73]. The evidence is inconclusive about the effect of heat treatment on CSF biomarkers; however, a heating step is unlikely to occur in or be recommended for routine clinical use.

\subsubsection{Centrifugation}

Centrifugation has been investigated often and is recommended in several standard protocols, particularly with haemorrhagic CSF samples (Table 1). However, results 
remain inconsistent (Table 4). Significant reductions in CSF A $(1-42)$ concentration following centrifugation have been reported $[73,141,143]$, possibly reflecting increased adhesion of $A \beta(1-42)$ to the cell walls, or precipitation of lysed cells during the process.

Leitao, et al. (2015) found no effect of different centrifugation speeds on CSF A $\beta(1-$ 42), tTau or pTau concentration except when total protein levels were high [114]. No significant differences were reported in CSF tTau or pTau concentration from including or omitting a centrifugation step $[100,114,130,141]$. Centrifugation may be required if samples contain some blood contamination (4.1.5 Blood contamination), and if so the step may reduce CSF $A \beta(1-42)$ but not tTau or pTau concentration

(Table 4). The potential reduction in $A \beta(1-42)$ must be taken into consideration, and we conclude centrifugation effects need further quantification if it is to be used sporadically to mitigate blood contamination.

\subsubsection{Shaking}

The effect of shaking on CSF biomarker concentration has not been extensively examined and is not listed in current protocols (Table 1). Shaking CSF samples for 48 hours at $R T$ led to a small but significant decrease in median $A \beta(1-42)$ concentration of $7 \%(n=20, P<.05)$ and tTau of $30 \%(n=20, P<.001 ;[144])$. Conversely, excessive vortexing did not have any effect on CSF A $\beta(1-42)$ concentration in a recent report [83]. Sample mixing may be more important if samples have been frozen and then thawed (Hansson O., personal observation). The benefits of creating more homogeneous samples by shaking or mixing, especially following freezing steps, requires further study. 


\subsection{Additional variables}

During this review process, a small number of potential pre-analytical variables were uncovered that have not received much consideration to date. This includes steps contained in current protocols without extensive investigation (for example, whether fasting before the CSF collection procedure is necessary), and also steps not included in current protocols for which some evidence indicates an influence on CSF biomarker concentration. The latter includes bacterial growth conditions, where bacterial contamination significantly reduced levels of $A \beta(1-42)$ and diminished tau concentration [144]. However, this could be alleviated by preventing bacterial growth with $0.1 \%$ sodium azide - which did not alter starting concentrations even after 5 days at RT [133]. In addition, tube sterilization methods can significantly increase their adsorbance properties (e.g., irradiation significantly increased the adsorbance properties of homopolymer tubes [121]). Further analysis into these potential variables may be required. 


\section{Discussion}

\subsection{Conclusions and recommendations}

The range of pre-analytical protocols used has introduced the potential for significant variability in CSF AD biomarker measurements. In this review, we summarized the current body of evidence and highlighted the most important key pre-analytical variable steps to consider in the future, such as tube material, the length of time samples are kept at RT before storage or analysis, and the relationship of tube surface area to sample volume (Fig. 2). In particular, CSF A $(1-42)$ concentration is significantly affected by tube type, with potentially important consequences for clinical and research evaluation. More consistent sample processing and a consensus on LoBind tube choice would help the field. In the future, it is also recommended that a better tube, capable of inhibiting CSF biomarker adsorption, be developed and adopted.

Although there are differences in the variables that specifically affect CSF $A \beta(1-42)$, tTau, and pTau, we found that generalizations could be made across these three biomarkers. In particular, our results showed that the variables (in addition to tube material) with the largest amount of conflicting data were: temperature between collection and analysis/storage, the number of freeze/thaw cycles advised, centrifugation and additives. In contrast, steps for which either little variability exists or where there is some consensus regarding parameters that should be followed were: CSF collection steps and storage time (although the effect of storage temperature and duration should be studied using new, high-precision assays). A number of pre-analytical variables may require further research, for example tube volume and shaking (Fig. 2). 
One limitation of this review may be that some unstudied variables or interactions of variables may yet have a significant influence on biomarker concentration. Further comprehensive research with more robust and precise assays will hopefully shed light on this. The wide variety in methodology in the research studies included in this review, where most studies did not combine several variables or measure several biomarkers in the same experiments, may make some comparisons weaker. In addition, this review was limited to analyzing evidence for pre-analytical variables affecting the concentration of CSF $A \beta(1-42)$, tTau, and pTau. Other biomarkers for $A D$ have been suggested, alone or in combination, for example $A \beta(1-38), A \beta(1-40)$, sAPPa, sAPPß, ApoE, neurofilament light, neurogranin, YKL-40 and VILIP-1 [39,145-147], and there is an emerging body of evidence for potential CSF biomarkers of other neurodegenerative disorders $[148,149]$.

We recommend that a universal pre-analytical protocol for CSF handling be developed and incorporated into future clinical trials, registries, and routine AD diagnosis. This protocol should attempt to control for the variables identified in this review as having the most influence on biomarker concentration. $A \beta(1-42)$ appeared to be the most affected by the pre-analytical variables evaluated; however, a universal protocol would reduce variability of all CSF biomarkers. This protocol could reflect the latest evidence on potentially important pre-analytical variables, while ideally being easy to implement and practical for clinical settings. Although clinical and analytical variables will still have an influence, a universal pre-analytical protocol will help enable accurate comparison of results between studies and further limit potential diagnostic variability. 


\section{Acknowledgements}

This review was funded by Roche Diagnostics $\mathrm{GmbH}$. The authors thank Helena Bailes, PhD, of MediTech Media, UK for providing editorial support, which was funded by Roche Diagnostics GmbH in accordance with Good Publication Practice (GPP3) guidelines (http://www.ismpp.org/gpp3).

Oskar Hansson is a Wallenberg Clinical Fellow and is supported by grants from the European and Swedish Research Councils.

Piotr Lewczuk received support from the Innovative Medicines Initiative Joint Undertaking under grant agreement $\mathrm{n} \cdot 115372$, resources of which are composed of financial contribution from the European Union's Seventh Framework Programme (FP7/2007-2013) and EFPIA companies' in kind contribution; he received consultation/lectures honoraria from AJ Roboscreen, IBL International, Fujirebio Europe, and Roche.

Kaj Blennow holds the Torsten Söderberg Professorship in Medicine.

Hugo Vanderstichele is a co-founder of ADx NeuroSciences and a founder of Biomarkable bvba.

Henrik Zetterberg is a Wallenberg Academy Fellow and is supported by grants from the Swedish and European Research Councils, as well as the Medical Research Council, UK.

Marcel Verbeek received funding via Alzheimer Nederland and the CAVIA project (number 733050202), which has been made possible by ZonMW. The CAVIA project is part of 'Memorabel', the research and innovation programme for dementia, as part of the Dutch national 'Deltaplan for Dementia': zonmw.nl/dementiaresearch. The 
CAVIA project is a consortium of Radboudumc, LUMC, Erasmus MC, VUmc, ADx NeuroSciences, Philips Healthcare, Stony Brook University, and Massachusetts General Hospital.

Charlotte Teunissen serves on the advisory board of Fujirebio and Roche and has performed contract research for Shire, Boehringer, Roche, Probiodrug, PeopleBio, Jansen Prevention Center. She has received grants from the Dutch Research Council (ZonMW), Association of Frontotemporal Dementia/Alzheimer's Drug Discovery Foundation/the Alzheimer's Drug Discovery Foundation, Alzheimer Netherlands, and the Weston Brain Institute.

Anne Fagan is supported by grants from the National Institutes of Health and has received research project funding from Roche Diagnostics, Fujirebio, and Biogen. Dr Fagan is on the Scientific Advisory Boards for Roche Diagnostics, IBL International and AbbVie and consults for Biogen, DiamiR, LabCorp, and Araclon Biotech/Griffols Leslie M Shaw receives funding from the Alzheimers Disease Neuroimaging Initiative (ADNI; NIA/NIH grant U19AG024904), MJFox Foundation for Parkinson's Disease Research, Lilly, and Roche 
Supplementary materials

\section{Appendix A}

Search terms used in PubMed literature search:

Search

1 ((pre-analytic* OR pre-analytic $\left.{ }^{*}\right)$ AND (CSF OR cerebrospinal fluid) AND ("1995"[Date - Publication] : "3000"[Date - Publication])

2 (variab* AND (CSF OR cerebrospinal fluid) AND (amyloid beta 42 OR amyloid- $\beta 42$ OR Aß42 OR Abeta42) AND ("1995"[Date - Publication] : "3000"[Date - Publication])

3 variab* AND (CSF OR cerebrospinal fluid) AND (phosphorylated tau OR ptau OR p-tau OR phospho tau OR phospho-tau) AND ("1995"[PDAT] : "3000"[PDAT])

4 (variab* AND (CSF OR cerebrospinal fluid) AND (total tau OR ttau OR ttau OR totaltau OR total-tau) AND ("1995"[Date - Publication] : "3000"[Date - Publication])

5 validation AND (CSF OR cerebrospinal fluid) AND biomarker* AND (alzheimer's OR alzheimer OR AD) AND (amyloid beta 42 OR amyloid- $\beta$ 42 OR Aß42 OR Abeta42 OR phosphorylated tau OR ptau OR p-tau OR phospho tau OR phospho-tau OR total tau OR ttau OR t-tau OR totaltau OR total-tau) AND ("1995"[Date - Publication] : "3000"[Date Publication]) 


\section{References}

[1] Dubois B, Feldman HH, Jacova C, Dekosky ST, Barberger-Gateau P, Cummings $\mathrm{J}$, et al. Research criteria for the diagnosis of Alzheimer's disease: revising the NINCDS-ADRDA criteria. Lancet Neurol 2007;6:734-46.

[2] Mattsson N, Zetterberg H, Hansson O, Andreasen N, Parnetti L, Jonsson M, et al. CSF biomarkers and incipient Alzheimer disease in patients with mild cognitive impairment. JAMA : the journal of the American Medical Association 2009;302:38593.

[3] Sperling R, Mormino E, Johnson K. The evolution of preclinical Alzheimer's disease: implications for prevention trials. Neuron 2014;84:608-22.

[4] Blennow K, Dubois B, Fagan AM, Lewczuk P, de Leon MJ, Hampel H. Clinical utility of cerebrospinal fluid biomarkers in the diagnosis of early Alzheimer's disease. Alzheimers Dement 2015;11:58-69.

[5] Hansson O, Zetterberg H, Buchhave P, Londos E, Blennow K, Minthon L. Association between CSF biomarkers and incipient Alzheimer's disease in patients with mild cognitive impairment: a follow-up study. Lancet neurology 2006;5:228-34.

[6] Mattsson N, Lonneborg A, Boccardi M, Blennow K, Hansson O, Geneva Task Force for the Roadmap of Alzheimer's Biomarkers. Clinical validity of cerebrospinal fluid Abeta42, tau, and phospho-tau as biomarkers for Alzheimer's disease in the context of a structured 5-phase development framework. Neurobiol Aging 2017;52:196-213. 
[7] Visser PJ, Verhey F, Knol DL, Scheltens P, Wahlund LO, Freund-Levi Y, et al. Prevalence and prognostic value of CSF markers of Alzheimer's disease pathology in patients with subjective cognitive impairment or mild cognitive impairment in the DESCRIPA study: a prospective cohort study. Lancet Neurol 2009;8:619-27.

[8] Jack CR, Knopman DS, Jagust WJ, Petersen RC, Weiner MW, Aisen PS, et al. Tracking pathophysiological processes in Alzheimer's disease: an updated hypothetical model of dynamic biomarkers. Lancet neurology 2013;12:207-16.

[9] Gustafson DR, Skoog I, Rosengren L, Zetterberg H, Blennow K. Cerebrospinal fluid beta-amyloid 1-42 concentration may predict cognitive decline in older women. J Neurol Neurosurg Psychiatry 2007;78:461-64.

[10] Stomrud E, Hansson O, Blennow K, Minthon L, Londos E. Cerebrospinal fluid biomarkers predict decline in subjective cognitive function over 3 years in healthy elderly. Dement Geriatr Cogn Disord 2007;24:118-24.

[11] van Harten AC, Visser PJ, Pijnenburg YA, Teunissen CE, Blankenstein MA, Scheltens $\mathrm{P}$, et al. Cerebrospinal fluid Abeta42 is the best predictor of clinical progression in patients with subjective complaints. Alzheimers Dement 2013;9:48187.

[12] Vos SJ, Xiong C, Visser PJ, Jasielec MS, Hassenstab J, Grant EA, et al. Preclinical Alzheimer's disease and its outcome: a longitudinal cohort study. Lancet Neurol 2013;12:957-65.

[13] Strimbu K, Tavel JA. What are biomarkers? Curr Opin HIV AIDS 2010;5:463-66. 
[14] Blennow K, Hampel H, Weiner M, Zetterberg H. Cerebrospinal fluid and plasma biomarkers in Alzheimer disease. Nature reviews. Neurology 2010;6:131-44.

[15] Lewczuk P, Esselmann H, Bibl M, Beck G, Maler JM, Otto M, et al. Tau protein phosphorylated at threonine 181 in CSF as a neurochemical biomarker in Alzheimer's disease: original data and review of the literature. $\mathrm{J}$ Mol Neurosci 2004;23:115-22.

[16] Fagan AM, Mintun MA, Shah AR, Aldea P, Roe CM, Mach RH, et al. Cerebrospinal fluid tau and ptau(181) increase with cortical amyloid deposition in cognitively normal individuals: implications for future clinical trials of Alzheimer's disease. EMBO Mol Med 2009;1:371-80.

[17] Shaw LM, Vanderstichele H, Knapik-Czajka M, Clark CM, Aisen PS, Petersen $\mathrm{RC}$, et al. Cerebrospinal fluid biomarker signature in Alzheimer's disease neuroimaging initiative subjects. Ann Neurol 2009;65:403-13.

[18] Janelidze S, Zetterberg H, Mattsson N, Palmqvist S, Vanderstichele H, Lindberg O, et al. CSF Abeta42/Abeta40 and Abeta42/Abeta38 ratios: better diagnostic markers of Alzheimer disease. Ann Clin Transl Neurol 2016;3:154-65.

[19] Duits FH, Teunissen CE, Bouwman FH, Visser PJ, Mattsson N, Zetterberg H, et al. The cerebrospinal fluid "Alzheimer profile": easily said, but what does it mean? Alzheimers Dement 2014;10:713-23.e2.

[20] Hertze J, Minthon L, Zetterberg H, Vanmechelen E, Blennow K, Hansson O. Evaluation of CSF biomarkers as predictors of Alzheimer's disease: a clinical followup study of 4.7 years. J Alzheimers Dis 2010;21:1119-28. 
[21] Buchhave P, Minthon L, Zetterberg H, Wallin AK, Blennow K, Hansson O. Cerebrospinal fluid levels of beta-amyloid 1-42, but not of tau, are fully changed already 5 to 10 years before the onset of Alzheimer dementia. Arch Gen Psychiatry 2012;69:98-106.

[22] Seeburger JL, Holder DJ, Combrinck M, Joachim C, Laterza O, Tanen M, et al. Cerebrospinal fluid biomarkers distinguish postmortem-confirmed Alzheimer's disease from other dementias and healthy controls in the OPTIMA cohort. J Alzheimers Dis 2015;44:525-39.

[23] Masters CL, Simms G, Weinman Na, Multhaup G, McDonald BL, Beyreuther K. Amyloid plaque core protein in Alzheimer disease and Down syndrome. Proc Natl Acad Sci U S A 1985;82:4245-9.

[24] Glenner GG, Wong CW. Alzheimer's disease: initial report of the purification and characterization of a novel cerebrovascular amyloid protein. Biochem Biophys Res Commun 1984; 120:885-90.

[25] Portelius E, Bogdanovic N, Gustavsson MK, Volkmann I, Brinkmalm G, Zetterberg $\mathrm{H}$, et al. Mass spectrometric characterization of brain amyloid beta isoform signatures in familial and sporadic Alzheimer's disease. Acta Neuropathol 2010;120:185-93.

[26] Arneric SP, Batrla-Utermann R, Beckett L, Bittner T, Blennow K, Carter L, et al. Cerebrospinal fluid biomarkers for alzheimer's disease: a view of the regulatory science qualification landscape from the coalition against major diseases CSF biomarker team. J Alzheimers Dis 2017;55:19-35. 
[27] Mattsson N, Carrillo MC, Dean RA, Devous MD S, Nikolcheva T, Pesini P, et al. Revolutionizing Alzheimer's disease and clinical trials through biomarkers.

Alzheimers Dement (Amst) 2015;1:412-19.

[28] Bittner T, Zetterberg H, Teunissen CE, Ostlund RE Jr, Militello M, Andreasson $U$, et al. Technical performance of a novel, fully automated electrochemiluminescence immunoassay for the quantitation of beta-amyloid (1-42) in human cerebrospinal fluid. Alzheimers Dement 2016;12:517-26.

[29] Buerger K, Frisoni G, Uspenskaya O, Ewers M, Zetterberg H, Geroldi C, et al. Validation of Alzheimer's disease CSF and plasma biological markers: the multicentre reliability study of the pilot European Alzheimer's Disease Neuroimaging Initiative (E-ADNI). Exp Gerontol 2009;44:579-85.

[30] Jansen WJ, Ossenkoppele R, Knol DL, Tijms BM, Scheltens P, Verhey FR, et al. Prevalence of cerebral amyloid pathology in persons without dementia: a metaanalysis. JAMA 2015;313:1924-38.

[31] Vlassenko AG, McCue L, Jasielec MS, Su Y, Gordon BA, Xiong C, et al. Imaging and cerebrospinal fluid biomarkers in early preclinical alzheimer disease. Ann Neurol 2016;80:379-87.

[32] Weigand SD, Vemuri P, Wiste HJ, Senjem ML, Pankratz VS, Aisen PS, et al. Transforming cerebrospinal fluid Abeta42 measures into calculated Pittsburgh Compound B units of brain Abeta amyloid. Alzheimers Dement 2011;7:133-41. 
[33] Grimmer T, Riemenschneider M, Forstl H, Henriksen G, Klunk WE, Mathis CA, et al. Beta amyloid in Alzheimer's disease: increased deposition in brain is reflected in reduced concentration in cerebrospinal fluid. Biol Psychiatry 2009;65:927-34.

[34] Strozyk D, Blennow K, White LR, Launer LJ. CSF Abeta 42 levels correlate with amyloid-neuropathology in a population-based autopsy study. Neurology 2003;60:652-56.

[35] Palmqvist S, Zetterberg H, Blennow K, Vestberg S, Andreasson U, Brooks DJ, et al. Accuracy of brain amyloid detection in clinical practice using cerebrospinal fluid beta-amyloid 42: A cross-validation study against amyloid positron emission tomography. JAMA Neurol 2014;71:1282-89.

[36] Fagan AM, Mintun MA, Mach RH, Lee SY, Dence CS, Shah AR, et al. Inverse relation between in vivo amyloid imaging load and cerebrospinal fluid Abeta42 in humans. Ann Neurol 2006;59:512-19.

[37] Lewczuk P, Matzen A, Blennow K, Parnetti L, Molinuevo JL, Eusebi P, et al. Cerebrospinal fluid abeta42/40 corresponds better than abeta42 to amyloid PET in alzheimer's disease. J Alzheimers Dis 2017;55:813-22.

[38] Palmqvist S, Zetterberg H, Mattsson N, Johansson P, Alzheimer's Disease Neuroimaging Initiative, Minthon L, et al. Detailed comparison of amyloid PET and CSF biomarkers for identifying early Alzheimer disease. Neurology 2015;85:1240_ 49. 
[39] Tarawneh R, Lee JM, Ladenson JH, Morris JC, Holtzman DM. CSF VILIP-1 predicts rates of cognitive decline in early Alzheimer disease. Neurology 2012;78:709-19.

[40] Fagan AM, Roe CM, Xiong C, Mintun MA, Morris JC, Holtzman DM. Cerebrospinal fluid tau/beta-amyloid(42) ratio as a prediction of cognitive decline in nondemented older adults. Arch Neurol 2007;64:343-9.

[41] Wiltfang J, Esselmann H, Bibl M, Hull M, Hampel H, Kessler H, et al. Amyloid beta peptide ratio $42 / 40$ but not $\mathrm{A}$ beta 42 correlates with phospho-Tau in patients with low- and high-CSF A beta 40 load. J Neurochem 2007;101:1053-9.

[42] Liu CC, Kanekiyo T, Xu H, Bu G. Apolipoprotein E and Alzheimer disease: risk, mechanisms and therapy. Nat Rev Neurol 2013;9:106-18.

[43] Wallin AK, Blennow K, Andreasen N, Minthon L. CSF biomarkers for Alzheimer's Disease: levels of beta-amyloid, tau, phosphorylated tau relate to clinical symptoms and survival. Dement Geriatr Cogn Disord 2006;21:131-8.

[44] van Rossum IA, Vos SJ, Burns L, Knol DL, Scheltens $P$, Soininen H, et al. Injury markers predict time to dementia in subjects with $\mathrm{MCl}$ and amyloid pathology. Neurology 2012;79:1809-16.

[45] Olsson B, Lautner R, Andreasson U, Ohrfelt A, Portelius E, Bjerke M, et al. CSF and blood biomarkers for the diagnosis of Alzheimer's disease: a systematic review and meta-analysis. Lancet Neurol 2016;15:673-84. 
[46] Hesse C, Rosengren L, Vanmechelen E, Vanderstichele H, Jensen C, Davidsson P, et al. Cerebrospinal fluid markers for Alzheimer's disease evaluated after acute ischemic stroke. J Alzheimers Dis 2000;2:199-206.

[47] Kouri N, Murray ME, Hassan A, Rademakers R, Uitti RJ, Boeve BF, et al. Neuropathological features of corticobasal degeneration presenting as corticobasal syndrome or Richardson syndrome. Brain 2011;134:3264-75.

[48] Skillback T, Rosen C, Asztely F, Mattsson N, Blennow K, Zetterberg H.

Diagnostic performance of cerebrospinal fluid total tau and phosphorylated tau in Creutzfeldt-Jakob disease: results from the Swedish Mortality Registry. JAMA Neurol 2014;71:476-83.

[49] Leow AD, Yanovsky I, Parikshak N, Hua X, Lee S, Toga AW, et al. Alzheimer's disease neuroimaging initiative: a one-year follow up study using tensor-based morphometry correlating degenerative rates, biomarkers and cognition. Neuroimage 2009;45:645-55.

[50] Seppala TT, Nerg O, Koivisto AM, Rummukainen J, Puli L, Zetterberg H, et al. CSF biomarkers for Alzheimer disease correlate with cortical brain biopsy findings. Neurology 2012;78:1568-75.

[51] Tapiola T, Alafuzoff I, Herukka SK, Parkkinen L, Hartikainen P, Soininen H, et al. Cerebrospinal fluid \{beta\}-amyloid 42 and tau proteins as biomarkers of Alzheimertype pathologic changes in the brain. Arch Neurol 2009;66:382-9. 
[52] Engelborghs S, Sleegers K, Cras P, Brouwers N, Serneels S, De Leenheir E, et al. No association of CSF biomarkers with APOEepsilon4, plaque and tangle burden in definite Alzheimer's disease. Brain 2007;130:2320-6.

[53] Hu YY, He SS, Wang X, Duan QH, Grundke-lqbal I, lqbal K, et al. Levels of nonphosphorylated and phosphorylated tau in cerebrospinal fluid of Alzheimer's disease patients : an ultrasensitive bienzyme-substrate-recycle enzyme-linked immunosorbent assay. Am J Pathol 2002;160:1269-78.

[54] Vanderstichele H, De Vreese K, Blennow K, Andreasen N, Sindic C, Ivanoiu A, et al. Analytical performance and clinical utility of the INNOTEST PHOSPHOTAU181P assay for discrimination between Alzheimer's disease and dementia with Lewy bodies. Clin Chem Lab Med 2006;44:1472-80.

[55] Buerger K, Ewers M, Pirttila T, Zinkowski R, Alafuzoff I, Teipel SJ, et al. CSF phosphorylated tau protein correlates with neocortical neurofibrillary pathology in Alzheimer's disease. Brain 2006;129:3035-41.

[56] Hampel H, Buerger K, Zinkowski R, Teipel SJ, Goernitz A, Andreasen N, et al. Measurement of phosphorylated tau epitopes in the differential diagnosis of Alzheimer disease: a comparative cerebrospinal fluid study. Arch Gen Psychiatry 2004;61:95-102.

[57] Meredith JE Jr, Sankaranarayanan S, Guss V, Lanzetti AJ, Berisha F, Neely RJ, et al. Characterization of novel CSF Tau and ptau biomarkers for Alzheimer's disease. PLoS One 2013;8:e76523. 
[58] McKhann GM, Knopman DS, Chertkow H, Hyman BT, Jack CR,Jr, Kawas CH, et al. The diagnosis of dementia due to Alzheimer's disease: recommendations from the National Institute on Aging-Alzheimer's Association workgroups on diagnostic guidelines for Alzheimer's disease. Alzheimers Dement 2011;7:263-9.

[59] Albert MS, DeKosky ST, Dickson D, Dubois B, Feldman HH, Fox NC, et al. The diagnosis of mild cognitive impairment due to Alzheimer's disease: recommendations from the National Institute on Aging-Alzheimer's Association workgroups on diagnostic guidelines for Alzheimer's disease.

Alzheimer's \& dementia : the journal of the Alzheimer's Association 2011;7:270-9.

[60] Dubois B, Feldman HH, Jacova C, Hampel H, Molinuevo JL, Blennow K, et al. Advancing research diagnostic criteria for Alzheimer's disease: the IWG-2 criteria. Lancet Neurol 2014;13:614-29.

[61] Sorbi S, Hort J, Erkinjuntti T, Fladby T, Gainotti G, Gurvit H, et al. EFNS-ENS Guidelines on the diagnosis and management of disorders associated with dementia. Eur J Neurol 2012;19:1159-79.

[62] Blennow K, Hampel H. CSF markers for incipient Alzheimer's disease. Lancet neurology 2003;2:605-13.

[63] Blennow K, Vanmechelen E, Hampel H. CSF total tau, Abeta42 and phosphorylated tau protein as biomarkers for Alzheimer's disease. Mol Neurobiol 2001;24:87-97.

[64] Lewczuk P, Kornhuber J, German Dementia Competence Network, Toledo JB, Trojanowski JQ, Knapik-Czajka M, et al. Validation of the Erlangen Score Algorithm 
for the prediction of the development of dementia due to alzheimer's disease in predementia subjects. J Alzheimers Dis 2015;48:433-41.

[65] Stomrud E, Minthon L, Zetterberg H, Blennow K, Hansson O.

Longitudinal cerebrospinal fluid biomarker measurements in preclinical sporadic Alzheimer's disease: A prospective 9-year study. Alzheimers Dement (Amst) 2015;1:403-11.

[66] Li G, Sokal I, Quinn JF, Leverenz JB, Brodey M, Schellenberg GD, et al. CSF tau/Abeta42 ratio for increased risk of mild cognitive impairment: a follow-up study. Neurology 2007;69:631-39.

[67] Verwey NA, van der Flier WM, Blennow K, Clark C, Sokolow S, De Deyn PP, et al. A worldwide multicentre comparison of assays for cerebrospinal fluid biomarkers in Alzheimer's disease. Ann Clin Biochem 2009;46:235-40.

[68] Lewczuk P, Beck G, Ganslandt O, Esselmann H, Deisenhammer F, Regeniter A, et al. International quality control survey of neurochemical dementia diagnostics. Neurosci Lett 2006;409:1-4.

[69] Hort J, Bartos a, Pirttilãa T, Scheltens P. Use of cerebrospinal fluid biomarkers in diagnosis of dementia across Europe. Eur J Neurol 2010;17:90-6.

[70] Garcia Barrado L, Coart E, Vanderstichele HM, Burzykowski T. Transferring cutoff values between assays for cerebrospinal fluid Alzheimer's disease biomarkers. $J$ Alzheimers Dis 2016;49:187-99.

[71] Vanderstichele H, Bibl M, Engelborghs S, Le Bastard N, Lewczuk P, Molinuevo $\mathrm{JL}$, et al. Standardization of preanalytical aspects of cerebrospinal fluid biomarker 
testing for Alzheimer's disease diagnosis: a consensus paper from the Alzheimer's Biomarkers Standardization Initiative. Alzheimers Dement 2012;8:65-73.

[72] Mattsson N, Andreasson U, Persson S, Carrillo MC, Collins S, Chalbot S, et al. CSF biomarker variability in the Alzheimer's Association Quality Control Program. Alzheimers Dement 2013;9:251-61.

[73] Bjerke M, Portelius E, Minthon L, Wallin A, Anckarsäter H, Anckarsäter R, et al. Confounding factors influencing amyloid Beta concentration in cerebrospinal fluid. Int J Alzheimer's Dis 2010;2010:1-11.

[74] Teunissen CE, Petzold A, Bennett JL, Berven FS, Brundin L, Comabella M, et al. A consensus protocol for the standardization of cerebrospinal fluid collection and biobanking. Neurology 2009;73:1914-22.

[75] Kuhlmann J, Andreasson U, Pannee J, Bjerke M, Portelius E, Leinenbach A, et al. CSF Abeta1-42 - an excellent but complicated Alzheimer's biomarker - a route to standardisation. Clin Chim Acta 2017;467:27-33.

[76] Leinenbach A, Pannee J, Dulffer T, Huber A, Bittner T, Andreasson U, et al. Mass spectrometry-based candidate reference measurement procedure for quantification of amyloid-beta in cerebrospinal fluid. Clin Chem 2014;60:987-94.

[77] Korecka M, Waligorska T, Figurski M, Toledo JB, Arnold SE, Grossman M, et al. Qualification of a surrogate matrix-based absolute quantification method for amyloidî242 in human cerebrospinal fluid using 2D UPLC-tandem mass spectrometry. J Alzheimer's dis 2014;41:441-51. 
[78] Mattsson N, Andreasson U, Persson S, Arai H, Batish SD, Bernardini S, et al. The Alzheimer's Association external quality control program for cerebrospinal fluid biomarkers. Alzheimers Dement 2011;7:386-95.e6.

[79] Carrillo MC, Blennow K, Soares H, Lewczuk P, Mattsson N, Oberoi P, et al. Global standardization measurement of cerebral spinal fluid for Alzheimer's disease: an update from the Alzheimer's Association Global Biomarkers Consortium. Alzheimers Dement 2013;9:137-40.

[80] del Campo M, Mollenhauer B, Bertolotto A, Engelborghs S, Hampel H, Simonsen $\mathrm{AH}$, et al. Recommendations to standardize preanalytical confounding factors in Alzheimer's and Parkinson's disease cerebrospinal fluid biomarkers: an update. Biomark Med 2012;6:419-30.

[81] Mattsson N, Blennow K, Zetterberg H. Inter-laboratory variation in cerebrospinal fluid biomarkers for Alzheimer's disease: united we stand, divided we fall. Clin Chem Lab Med 2010;48:603-7.

[82] Mo Y, Stromswold J, Wilson K, Holder D, Sur C, Laterza O, et al. A multinational study distinguishing Alzheimer's and healthy patients using cerebrospinal fluid tau/Abeta42 cutoff with concordance to amyloid positron emission tomography imaging. Alzheimers Dement (Amst) 2017;6:201-9.

[83] Willemse E, van Uffelen K, Brix B, Engelborghs S, Vanderstichele H, Teunissen C. How to handle adsorption of cerebrospinal fluid amyloid-beta (1-42) in laboratory practice? Identifying problematic handlings and resolving the issue by use of the Abeta42/Abeta40 ratio. Alzheimers Dement 2017;13:885-92. 
[84] Park SA, Kang JH, Kang ES, Ki CS, Roh JH, Youn YC, et al. A consensus in Korea regarding a protocol to reduce preanalytical sources of variability in the measurement of the cerebrospinal fluid biomarkers of Alzheimer's disease. J Clin Neurol 2015;11:132-41.

[85] Teunissen CE, Tumani H, Engelborghs S, Mollenhauer B. Biobanking of CSF: international standardization to optimize biomarker development. Clin Biochem 2014;47:288-92.

[86] Reijs BL, Teunissen CE, Goncharenko N, Betsou F, Blennow K, Baldeiras I, et al. The central biobank and virtual biobank of BIOMARKAPD: A resource for studies on neurodegenerative diseases. Front Neurol 2015;6:216.

[87] Lewczuk P, Kornhuber J, Wiltfang J. The German Competence Net Dementias: standard operating procedures for the neurochemical dementia diagnostics. J Neural Transm (Vienna) 2006;113:1075-80.

[88] Lewczuk P, Zimmermann R, Wiltfang J, Kornhuber J. Neurochemical dementia diagnostics: a simple algorithm for interpretation of the CSF biomarkers. J Neural Transm (Vienna) 2009;116:1163-67.

[89] Moghekar A, Goh J, Li M, Albert M, O'Brien RJ. Cerebrospinal fluid Abeta and tau level fluctuation in an older clinical cohort. Arch Neurol 2012;69:246-50.

[90] Cicognola C, Chiasserini D, Eusebi P, Andreasson U, Vanderstichele H, Zetterberg $\mathrm{H}$, et al. No diurnal variation of classical and candidate biomarkers of Alzheimer's disease in CSF. Mol Neurodegener 2016;11:65. 
[91] Bateman RJ, Wen G, Morris JC, Holtzman DM. Fluctuations of CSF amyloidbeta levels: implications for a diagnostic and therapeutic biomarker. Neurology 2007;68:666-9.

[92] Huang Y, Potter R, Sigurdson W, Santacruz A, Shih S, Ju YE, et al. Effects of age and amyloid deposition on Abeta dynamics in the human central nervous system. Arch Neurol 2012;69:51-8.

[93] Lucey BP, Gonzales C, Das U, Li J, Siemers ER, Slemmon JR, et al. An integrated multi-study analysis of intra-subject variability in cerebrospinal fluid amyloid-beta concentrations collected by lumbar puncture and indwelling lumbar catheter. Alzheimers Res Ther 2015;7:53.

[94] Van Broeck B, Timmers M, Ramael S, Bogert J, Shaw LM, Mercken M, et al. Impact of frequent cerebrospinal fluid sampling on Abeta levels: systematic approach to elucidate influencing factors. Alzheimers Res Ther 2016;8:21.

[95] Slats D, Claassen JA, Spies PE, Borm G, Besse KT, van Aalst W, et al. Hourly variability of cerebrospinal fluid biomarkers in Alzheimer's disease subjects and healthy older volunteers. Neurobiol Aging 2012;33:831.

[96] Lucey BP, Fagan AM, Holzman DM, Morris JC, Bateman RJ. Diurnal oscillation of CSF A $\beta$ and other AD biomarkers. Molecular Neurodegeneration 2017;12:36.

[97] Engelborghs S, Niemantsverdriet E, Struyfs H, Blennow K, Brouns R, Comabella $\mathrm{M}$, et al. Consensus guidelines for lumbar puncture in patients with neurological diseases. Alzheimers Dement (Amst) 2017;8:111-26. 
[98] Mollenhauer B, Trautmann E, Otte B, Ng J, Spreer A, Lange P, et al. Alphasynuclein in human cerebrospinal fluid is principally derived from neurons of the central nervous system. J Neural Transm (Vienna) 2012;119:739-46.

[99] Reiber H. Dynamics of brain-derived proteins in cerebrospinal fluid. Clin Chim Acta $2001 ; 310: 173-86$.

[100] Le Bastard N, De Deyn PP, Engelborghs S. Importance and impact of preanalytical variables on Alzheimer disease biomarker concentrations in cerebrospinal fluid. Clin Chem 2015;61:734-43.

[101] Aasebo E, Opsahl JA, Bjorlykke Y, Myhr KM, Kroksveen AC, Berven FS. Effects of blood contamination and the rostro-caudal gradient on the human cerebrospinal fluid proteome. PLoS One 2014;9:e90429.

[102] Djukic M, Spreer A, Lange P, Bunkowski S, Wiltfang J, Nau R. Small cisternolumbar gradient of phosphorylated Tau protein in geriatric patients with suspected normal pressure hydrocephalus. Fluids Barriers CNS 2016;13:15.

[103] Brandner S, Thaler C, Lelental N, Buchfelder M, Kleindienst A, Maler JM, et al. Ventricular and lumbar cerebrospinal fluid concentrations of Alzheimer's disease biomarkers in patients with normal pressure hydrocephalus and posttraumatic hydrocephalus. J Alzheimers Dis 2014;41:1057-62.

[104] Ohman S, Ernerudh J, Forsberg P, Roberg M, Vrethem M. Lower values for immunoglobulin M in cerebrospinal fluid when sampled with an atraumatic Sprotte needle compared with conventional lumbar puncture. Ann Clin Biochem 1995;32( Pt 2):210-2. 
[105] Duits FH, Martinez-Lage P, Paquet C, Engelborghs S, Lleo A, Hausner L, et al. Performance and complications of lumbar puncture in memory clinics: Results of the multicenter lumbar puncture feasibility study. Alzheimers Dement 2016;12:154-63.

[106] Peskind E, Nordberg A, Darreh-Shori T, Soininen H. Safety of lumbar puncture procedures in patients with Alzheimer's disease. Curr Alzheimer Res 2009;6:290-2.

[107] Rembach A, Evered LA, Li QX, Nash T, Vidaurre L, Fowler CJ, et al.

Alzheimer's disease cerebrospinal fluid biomarkers are not influenced by gravity drip or aspiration extraction methodology. Alzheimers Res Ther 2015;7:71-015-0157-7.

[108] Toombs J, Foiani MS, Paterson RW, Heslegrave A, Wray S, Schott JM, et al. Effect of spinal manometers on cerebrospinal fluid amyloid-beta concentration. $\mathrm{J}$ Alzheimers Dis 2017;56: 885-91.

[109] Shah KH, Richard KM, Nicholas S, Edlow JA. Incidence of traumatic lumbar puncture. Acad Emerg Med 2003;10:151-4.

[110] Biere AL, Ostaszewski B, Stimson ER, Hyman BT, Maggio JE, Selkoe DJ. Amyloid beta-peptide is transported on lipoproteins and albumin in human plasma. $\mathrm{J}$ Biol Chem 1996;271:32916-22.

[111] Portelius E, Mattsson N, Pannee J, Zetterberg H, Gisslen M, Vanderstichele H, et al. Ex vivo 180-labeling mass spectrometry identifies a peripheral amyloid beta clearance pathway. Mol Neurodegener 2017;12:18.

[112] Kiko T, Nakagawa K, Satoh A, Tsuduki T, Furukawa K, Arai H, et al. Amyloid beta levels in human red blood cells. PLoS One 2012;7:e49620. 
[113] Vanderstichele H, Van Kerschaver E, Hesse C, Davidsson P, Buyse MA, Andreasen N, et al. Standardization of measurement of beta-amyloid(1-42) in cerebrospinal fluid and plasma. Amyloid : the international journal of experimental and clinical investigation : the official journal of the International Society of Amyloidosis 2000;7:245-58.

[114] Leitao MJ, Baldeiras I, Herukka SK, Pikkarainen M, Leinonen V, Simonsen AH, et al. Chasing the effects of pre-analytical confounders - a multicenter study on CSFAD biomarkers. Front Neurol 2015;6:153.

[115] Hong Z, Shi M, Chung KA, Quinn JF, Peskind ER, Galasko D, et al. DJ-1 and alpha-synuclein in human cerebrospinal fluid as biomarkers of Parkinson's disease. Brain 2010;133:713-26.

[116] Barbour R, Kling K, Anderson JP, Banducci K, Cole T, Diep L, et al. Red blood cells are the major source of alpha-synuclein in blood. Neurodegener Dis 2008;5:559.

[117] Perret-Liaudet A, Pelpel M, Tholance Y, Dumont B, Vanderstichele H, Zorzi W, et al. Risk of Alzheimer's disease biological misdiagnosis linked to cerebrospinal collection tubes. J Alzheimers Dis 2012;31:13-20.

[118] Andreasen N, Hesse C, Davidsson P, Minthon L, Wallin A, Winblad B, et al. Cerebrospinal fluid beta-amyloid(1-42) in Alzheimer disease: differences between early- and late-onset Alzheimer disease and stability during the course of disease. Arch Neurol 1999;56:673-80. 
[119] Lewczuk P, Beck G, Esselmann H, Bruckmoser R, Zimmermann R, Fiszer M, et al. Effect of sample collection tubes on cerebrospinal fluid concentrations of tau proteins and amyloid beta peptides. Clin Chem 2006;52:332-4.

[120] Gervaise-Henry C, Watfa G, Albuisson E, Kolodziej A, Dousset B, Olivier JL, et al. Cerebrospinal fluid abeta42/abeta40 as a means to limiting tube- and storagedependent pre-analytical variability in clinical setting. J Alzheimers Dis 2017;57:43745.

[121] Kofanova OA, Mommaerts K, Betsou F. Tube polypropylene: a neglected critical parameter for protein adsorption during biospecimen storage. Biopreserv Biobank 2015;13:296-98.

[122] Pica-Mendez AM, Tanen M, Dallob A, Tanaka W, Laterza OF. Nonspecific binding of Abeta42 to polypropylene tubes and the effect of Tween-20. Clin Chim Acta 2010;411:1833.

[123] Cullen VC, Fredenburg Ra, Evans C, Conliffe PR, Solomon ME. Development and advanced validation of an optimized method for the quantitation of Abeta42 in human cerebrospinal fluid. The AAPS Journal 2012;14: 510-8.

[124] Vanderstichele HM, Janelidze S, Demeyer L, Coart E, Stoops E, Herbst V, et al. Optimized standard operating procedures for the analysis of cerebrospinal fluid abeta42 and the ratios of abeta isoforms using low protein binding tubes. $\mathrm{J}$ Alzheimers Dis 2016;53:1121-32.

[125] Toombs J, Paterson RW, Schott JM, Zetterberg H. Amyloid-beta 42 adsorption following serial tube transfer. Alzheimers Res Ther 2014;6:5. 
[126] Vanderstichele H, Demeyer L, Janelidze S, Coart E, Stoops E, Mauroo K, et al. Recommendations for cerebrospinal fluid collection for the analysis by ELISA of neurogranin trunc $\mathrm{P} 75$, alpha-synuclein, and total tau in combination with Abeta(142)/Abeta(1-40). Alzheimers Res Ther 2017;9:40.

[127] Toombs J, Paterson RW, Lunn MP, Nicholas JM, Fox NC, Chapman MD, et al. Identification of an important potential confound in CSF AD studies: aliquot volume. Clin Chem Lab Med 2013;51:2311-7.

[128] Paterson RW, Toombs J, Chapman MD, Nicholas JM, Heslegrave AJ, Slattery CF, et al. Do cerebrospinal fluid transfer methods affect measured amyloid beta42, total tau, and phosphorylated tau in clinical practice? Alzheimers Dement (Amst) $2015 ; 1: 380-4$.

[129] Kaiser E, Schönknecht P, Thomann PA, Hunt A, Schröder J. Influence of delayed CSF storage on concentrations of phospho-tau protein (181), total tau protein and beta-amyloid (1-42). Neurosci Lett 2007;417:193-5.

[130] Schoonenboom NSM, Mulder C, Vanderstichele H, Van Elk E, Kok A, Van Kamp GJ, et al. Effects of processing and storage conditions on amyloid beta (1-42) and tau concentrations in cerebrospinal fluid: implications for use in clinical practice. Clin Chem 2005;51:189-95.

[131] Zimmermann R, Lelental N, Ganslandt O, Maler JM, Kornhuber J, Lewczuk P. Preanalytical sample handling and sample stability testing for the neurochemical dementia diagnostics. Journal of Alzheimer's disease: JAD 2011;25:739-45. 
[132] Simonsen AH, Bahl JMC, Danborg PB, Lindstrom V, Larsen SO, Grubb A, et al. Pre-analytical factors influencing the stability of cerebrospinal fluid proteins. $J$ Neurosci Methods 2013;215:234-40.

[133] Lelental N, Brandner S, Kofanova O, Blennow K, Zetterberg H, Andreasson U, et al. Comparison of different matrices as potential quality control samples for neurochemical dementia diagnostics. J Alzheimers Dis 2016;52:51-64.

[134] Lachno DR, Romeo MJ, Siemers ER, Vanderstichele H, Coart E, Konrad RJ, et al. Validation of ELISA methods for quantification of total tau and phosporylatedtau181 in human cerebrospinal fluid with measurement in specimens from two Alzheimer's disease studies. J Alzheimers Dis 2011;26:531-41.

[135] Bruegel M, Planert M, Baumann S, Focke A, Bergh FT, Leichtle A, et al. Standardized peptidome profiling of human cerebrospinal fluid by magnetic bead separation and matrix-assisted laser desorption/ionization time-of-flight mass spectrometry. Journal of proteomics 2009;72:608-15.

[136] Rozga M, Bittner T, Hoglund K, Blennow K. Accuracy of cerebrospinal fluid Abeta1-42 measurements: evaluation of pre-analytical factors using a novel Elecsys immunosassay. Clin Chem Lab Med 2017;55:1545-1554.

[137] Andreasen N, Minthon L, Davidsson P, Vanmechelen E, Vanderstichele H, Winblad B, et al. Evaluation of CSF-tau and CSF-Abeta42 as diagnostic markers for Alzheimer disease in clinical practice. Arch Neurol 2001;58:373-79.

[138] Lachno DR, Evert BA, Maloney K, Willis BA, Talbot JA, Vandijck M, et al. Validation and clinical utility of ELISA methods for quantification of amyloid-beta of 
peptides in cerebrospinal fluid specimens from alzheimer's disease studies. $\mathrm{J}$ Alzheimers Dis 2015;45:527-42.

[139] Schipke CG, Jessen F, Teipel S, Luckhaus C, Wiltfang J, Esselmann H, et al. Long-term stability of Alzheimer's disease biomarker proteins in cerebrospinal fluid. Journal of Alzheimer's disease: JAD 2011;26:255-62.

[140] Willemse EAJ, van Uffelen KWJ, van der Flier WM, Teunissen CE. Effect of long-term storage in biobanks on cerebrospinal fluid biomarker Abeta1-42, T-tau, and P-tau values. Alzheimers Dement (Amst) 2017;8:45-50.

[141] Berge G, Lauridsen C, Sando SB, Holder DJ, Moller I, Aasly JO, et al. Effect of tween-20 on core biomarkers measured in cerebrospinal fluid from patients with alzheimer's disease, mild cognitive impairment, or healthy control individuals. J Alzheimers Dis 2016;49:493-502.

[142] Toombs J, Paterson RW, Nicholas JM, Petzold A, Schott JM, Zetterberg H. The impact of Tween 20 on repeatability of amyloid beta and tau measurements in cerebrospinal fluid. Clin Chem Lab Med 2015;53:e329-32.

[143] Hu WT, Watts KD, Shaw LM, Howell JC, Trojanowski JQ, Basra S, et al. CSF beta-amyloid 1-42 - what are we measuring in Alzheimer's disease? Ann Clin Transl Neurol 2015;2:131-9.

[144] Fronek K, Lange P, Spreer A, Eiffert H, Nau R. Bacterial contamination and the transport vial material affect cerebrospinal fluid concentrations of beta-Amyloid and Tau protein as determined by enzyme immunoassay. Dement Geriatr Cogn Disord 2011;32:126-34. 
[145] Mattsson N, Insel PS, Palmqvist S, Portelius E, Zetterberg H, Weiner M, et al. Cerebrospinal fluid tau, neurogranin, and neurofilament light in Alzheimer's disease. EMBO Mol Med 2016;8:1184-96.

[146] Rosen C, Andersson CH, Andreasson U, Molinuevo JL, Bjerke M, Rami L, et al. Increased levels of chitotriosidase and YKL-40 in cerebrospinal fluid from patients with alzheimer's disease. Dement Geriatr Cogn Dis Extra 2014;4:297-304.

[147] Lewczuk P, Kamrowski-Kruck H, Peters O, Heuser I, Jessen F, Popp J, et al. Soluble amyloid precursor proteins in the cerebrospinal fluid as novel potential biomarkers of Alzheimer's disease: a multicenter study. Mol Psychiatry 2010;15:13845.

[148] Blennow K, Biscetti L, Eusebi P, Parnetti L. Cerebrospinal fluid biomarkers in Alzheimer's and Parkinson's diseases-From pathophysiology to clinical practice. Mov Disord 2016;31:836-47.

[149] Benatar M, Boylan K, Jeromin A, Rutkove SB, Berry J, Atassi N, et al. ALS biomarkers for therapy development: State of the field and future directions. Muscle Nerve 2016;53:169-82.

[150] Biomedical Research Forum LLC. ALZFORUM ADNI procedures manual. 21 June 2017. Available at http://www.alzforum.org/sites/default/files (accessed August 2017).

[151] Alzheimer's Disease Neuroimaging Initiative. ADNI3 Procedures Manual Version 3.0. 2017; 20170627_v3.0. 
[152] Alzheimer's Association. The Alzheimer's Association flow chart for lumbar puncture and CSF processing; 21 June 2017. Available at http://www.alzforum.org/sites/default/files (accessed August 2017).

[153] Sjogren M, Vanderstichele H, Agren H, Zachrisson O, Edsbagge M, Wikkelso C, et al. Tau and Abeta42 in cerebrospinal fluid from healthy adults 21-93 years of age: establishment of reference values. Clin Chem 2001;47:1776-81.

[154] Verwey NA, Bouwman FH, van der Flier WM, Veerhuis R, Scheltens P, Blankenstein MA. Variability in longitudinal cerebrospinal fluid tau and phosphorylated tau measurements. Clin Chem Lab Med 2008;46:1300-4.

[155] Bibl M, Esselmann H, Otto M, Lewczuk P, Cepek L, Rüther E, et al. Cerebrospinal fluid amyloid beta peptide patterns in Alzheimer's disease patients and nondemented controls depend on sample pretreatment: indication of carriermediated epitope masking of amyloid beta peptides. Electrophoresis 2004;25:29128. 
Tables/Figures

듬음

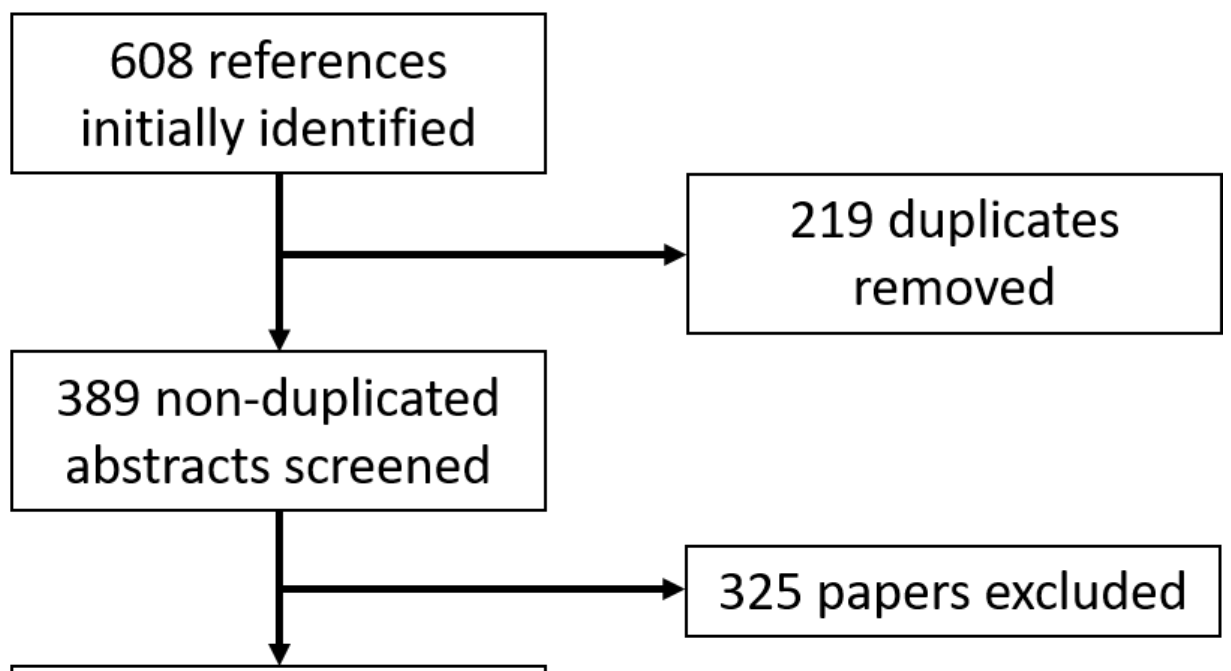

ปัֻ abstracts screened

references assessed

$\frac{\vec{t}}{\frac{0}{\overline{0}}}$

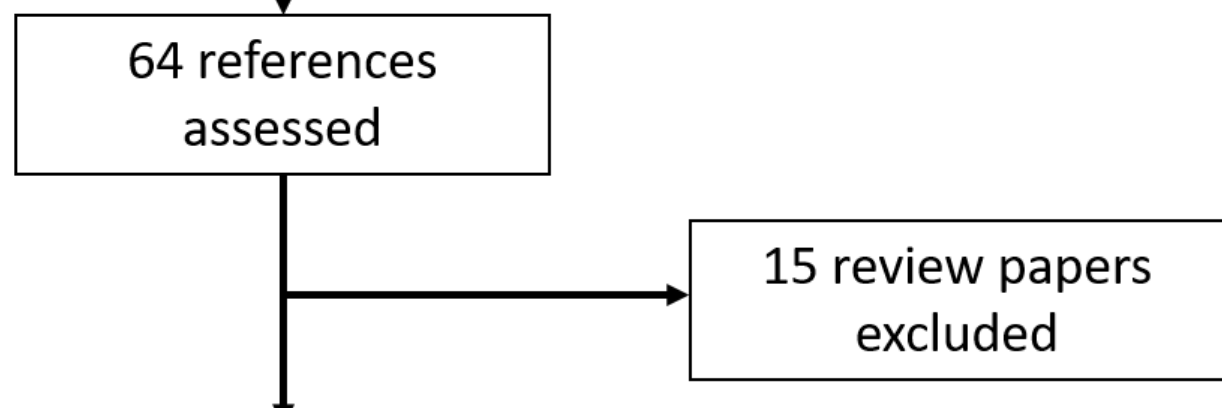

49 full-length studies included in qualitative synthesis

Fig. 1. PRISMA flow diagram of literature search and study selection flow for systematic reviews. 


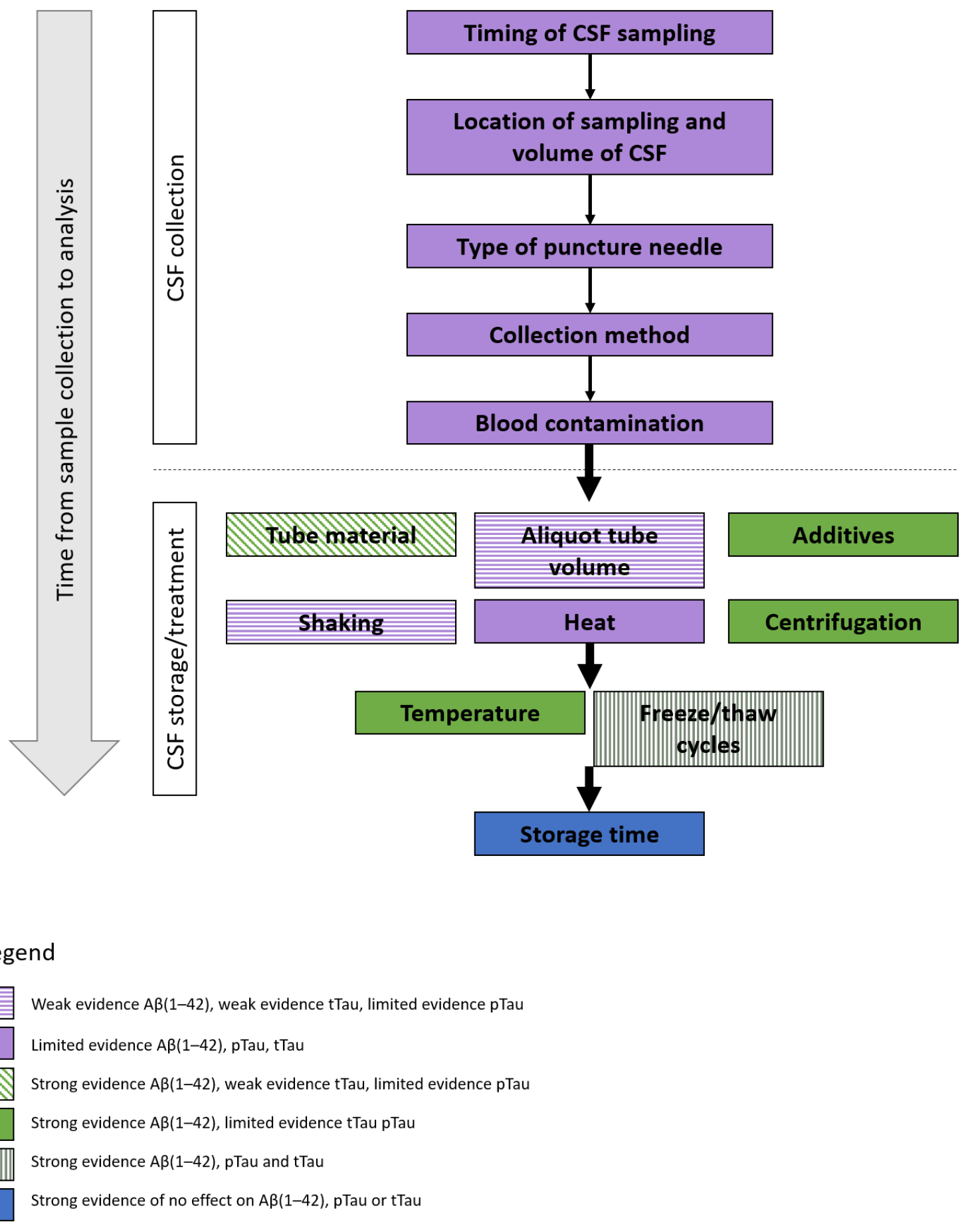

Fig. 2. Pre-analytical variables in CSF biomarker analysis.

Abbreviations: $A \beta, \beta$ amyloid; CSF, cerebrospinal fluid 
Table 1

Comparison of existing protocols used for pre-analytical handling of CSF samples before measuring concentrations of core AD biomarkers

\begin{tabular}{|c|c|c|c|c|c|c|}
\hline & $\begin{array}{c}\text { ADNI } \\
{[150][151][29]}\end{array}$ & $\begin{array}{c}\text { BioFINDER } \\
{[14,35]^{\star}}\end{array}$ & $\begin{array}{c}\text { BIOMARKAPD } \\
\text { [80] }\end{array}$ & $\begin{array}{c}\text { AA } \\
{[152]}\end{array}$ & $\begin{array}{l}\text { ABSI } \\
\text { [71] }\end{array}$ & $\begin{array}{c}\text { Standard } \\
\text { Biobanking } \\
\text { Protocol [85] }\end{array}$ \\
\hline $\begin{array}{l}\text { Fasting before } \\
\text { LP }\end{array}$ & Minimum $6 \mathrm{~h}$ & Not required & Not required & Not required & Not required & Not mentioned \\
\hline $\begin{array}{l}\text { Timing of CSF } \\
\text { sampling }\end{array}$ & Morning & $\begin{array}{l}\text { Standardized } \\
(0800-1200 \mathrm{~h})\end{array}$ & Day time & $0800-1200 \mathrm{~h}$ & Any time & $\begin{array}{c}\text { Standardized } \\
\text { within each } \\
\text { centre }\end{array}$ \\
\hline $\begin{array}{l}\text { Location of } \\
\text { sampling (LP) }\end{array}$ & L3-L5 & L3-L5 & L3-L5 & L3-L5 & L3-L5 & L3-L5 \\
\hline $\begin{array}{l}\text { Type of LP } \\
\text { needle }\end{array}$ & $\begin{array}{c}22 \mathrm{G} \text { and } 24 \mathrm{G} \\
\text { atraumatic }\end{array}$ & $22 \mathrm{G}$ atraumatic & 25G atraumatic & 22G, atraumatic & 22G, atraumatic & Atraumatic \\
\hline
\end{tabular}




\begin{tabular}{|c|c|c|c|c|c|c|}
\hline $\begin{array}{l}\text { Collection } \\
\text { method }\end{array}$ & $\begin{array}{l}\text { Gravity drip } \\
\qquad(22 G, \\
\text { recommended) } \\
\text { or suction (24G) }\end{array}$ & Gravity drip & Not specified & Not specified & Not specified & Not specified \\
\hline Tube type & PP (Sarstedt) & PP & PP & PP & $\begin{array}{c}\text { PP - } \\
\text { standardized } \\
\text { small volume }\end{array}$ & PP, screw cap \\
\hline $\begin{array}{l}\text { Collection } \\
\text { volume (mL) }\end{array}$ & $15-20$ & $\begin{array}{c}10 \times 2 \text {, gentle } \\
\operatorname{mix}\end{array}$ & 12 & $\begin{array}{c}\text { 10-12, gentle } \\
\text { mix }\end{array}$ & $\geq 1.5$ & 12 \\
\hline $\begin{array}{l}\text { Temperature } \\
\text { between } \\
\text { collection and } \\
\text { analysis/storage }\end{array}$ & $\begin{array}{l}\text { One transfer (for } \\
\text { shipping), dry } \\
\text { ice }\end{array}$ & $\begin{array}{c}\mathrm{RT}<30 \text { mins, } \\
\text { freeze and ship } \\
\text { on dry ice if } \\
\text { longer }\end{array}$ & $<5$ days, $4^{\circ} \mathrm{C}$ & $\mathrm{RT}<2$ days & $\mathrm{RT}<5$ days & $\begin{array}{l}\text { RT, 30-60 mins } \\
\text { (max } 2 \text { hours), } \\
\text { ship on dry ice }\end{array}$ \\
\hline $\begin{array}{l}\text { Blood } \\
\text { contamination }\end{array}$ & $\begin{array}{l}\text { Should be clear } \\
\qquad \text { CSF only; } \\
\text { discard initial 1- }\end{array}$ & $\begin{array}{l}\text { Discard initial } \\
1-2 \mathrm{~mL} \text { if bloody }\end{array}$ & $\begin{array}{c}<50 \\
\text { erythrocytes } / \mu \mathrm{L} \\
\text { CSF (for }\end{array}$ & $\begin{array}{l}\text { Should be clear } \\
\text { CSF only; } \\
\text { discard initial }\end{array}$ & $\begin{array}{l}\qquad 50 \\
\text { erythrocytes } / \mu \mathrm{L} \\
\text { CSF. Discard }\end{array}$ & $\begin{array}{c}<50 \\
\text { erythrocytes } / \mu \mathrm{L} \\
\text { CSF }\end{array}$ \\
\hline
\end{tabular}




\begin{tabular}{|c|c|c|c|c|c|c|}
\hline & $\begin{array}{c}2 \mathrm{~mL} \text { (or more if } \\
\text { needed) }\end{array}$ & & $\begin{array}{l}\text { biomarkers } \\
\text { highly abundant } \\
\text { in peripheral } \\
\text { blood) }\end{array}$ & $\begin{array}{l}0.5-1 \mathrm{~mL} \text { (or } \\
\text { more if needed) }\end{array}$ & $\begin{array}{l}\text { initial } 1-2 \mathrm{~mL} \text { if } \\
\text { bloody }\end{array}$ & \\
\hline Centrifugation & $\begin{array}{c}\text { No [151]; } \\
\text { yes } 2000 \text { x g } 10 \\
\text { mins } 4^{\circ} \mathrm{C} \text { [29] }\end{array}$ & $\begin{array}{c}\text { Yes- } 2000 \times g \\
10 \text { mins RT }\end{array}$ & $\begin{array}{c}\text { Yes }-2000 \times g \\
10 \text { mins RT }\end{array}$ & Yes & $\begin{array}{c}\text { No (unless } \\
\text { visually } \\
\text { haemorrhagic; } \\
2000 \text { x g } 10 \\
\text { mins RT) }\end{array}$ & $\begin{array}{c}\text { Yes }-2000 \times g \\
10 \text { mins RT }\end{array}$ \\
\hline $\begin{array}{l}\text { Freezing } \\
\text { temperature } \\
\left({ }^{\circ} \mathrm{C}\right)\end{array}$ & $\begin{array}{c}-80^{\circ} \mathrm{C} \text { (following } \\
\text { dry ice) }\end{array}$ & $-80^{\circ} \mathrm{C}$ & $-80^{\circ} \mathrm{C}$ & $-80^{\circ} \mathrm{C}$ & $-80^{\circ} \mathrm{C}$ & $-80^{\circ} \mathrm{C}$ \\
\hline $\begin{array}{l}\text { Aliquots } \\
\text { Volume (mL) }\end{array}$ & $0.5[29]$ & $\leq 1$ & $0.25-0.5$ tubes & 1 & small & $\begin{array}{l}0.1-0.75 \\
\text { aliquots in 1- } \\
2 \mathrm{~mL} \text { tubes }\end{array}$ \\
\hline
\end{tabular}




\begin{tabular}{|c|c|c|c|c|c|c|}
\hline Fill level (\%) & Not specified & $\geq 50$ & $>75$ & Not specified & $\geq 50$ & 75 \\
\hline $\begin{array}{l}\text { Freeze/thaw } \\
\text { cycles }(n)\end{array}$ & $\leq 2$ & 1 & $\leq 2$ & 1 & $\leq 2$ & 1 \\
\hline $\begin{array}{l}\text { Storage time } \\
\text { (years) }\end{array}$ & Not specified & Not specified & $\leq 2$ & Not specified & $\leq 2$ & Not specified \\
\hline
\end{tabular}

*Hansson O, personal communication.

Abbreviations: AA, Alzheimer's Association; ABSI, Alzheimer's Biomarkers Standardization Initiative; ADNI, Alzheimer's Disease Neuroimaging Initiative; CSF, cerebrospinal fluid; LP, lumbar puncture; PP, polypropylene; RT, room temperature. 
Table 2

The influence of LP on CSF core AD biomarker concentration

\begin{tabular}{|c|c|c|c|c|c|c|}
\hline \multirow{2}{*}{$\begin{array}{l}\text { Pre- } \\
\text { analytical } \\
\text { variable }\end{array}$} & \multicolumn{2}{|c|}{$A \beta(1-42)$} & \multicolumn{2}{|c|}{ tTau } & \multicolumn{2}{|c|}{ pTau } \\
\hline & $\begin{array}{l}\text { Evidence of } \\
\text { influence of } \\
\text { variable }\end{array}$ & $\begin{array}{c}\text { Evidence of no } \\
\text { influence of } \\
\text { variable }\end{array}$ & $\begin{array}{l}\text { Evidence of } \\
\text { influence of } \\
\text { variable }\end{array}$ & $\begin{array}{c}\text { Evidence of no } \\
\text { influence of } \\
\text { variable }\end{array}$ & $\begin{array}{l}\text { Evidence of } \\
\text { influence of } \\
\text { variable }\end{array}$ & $\begin{array}{c}\text { Evidence of no } \\
\text { influence of } \\
\text { variable }\end{array}$ \\
\hline $\begin{array}{l}\text { Timing of } \\
\text { CSF } \\
\text { sampling }\end{array}$ & $\begin{array}{c}\text { 1.5-4-fold } \\
\text { change [91], } \\
\text { slight but } \\
\text { significant } \\
\downarrow 9.3 \% \text { after } \\
\sim 5 \text { hours, return } \\
\text { after } 24 \text { hours } \\
\text { [73]; low }\end{array}$ & $\begin{array}{l}\text { No significant } \\
\text { effect }[89,90] \text {, } \\
\text { CV } 5.5 \%[89]\end{array}$ & $\begin{array}{c}\text { Linear } \uparrow \text { over } 36 \\
\text { hours in AD } \\
\text { patients only } \\
{[95]}\end{array}$ & $\begin{array}{c}\text { No significant } \\
\text { effect }[89,90,95] \\
\text { CV } 8.2 \%[89]\end{array}$ & $\begin{array}{l}\text { Linear } \uparrow \text { over } \\
36 \text { hours in AD } \\
\text { patients only } \\
\text { and significant } \\
\text { fluctuation } \\
\text { pattern in both } \\
\text { AD patients and } \\
\text { controls [95] }\end{array}$ & $\begin{array}{l}\text { No significant } \\
\text { effect [90], not } \\
\text { significant, CV } \\
11.9 \% \text { [89] }\end{array}$ \\
\hline
\end{tabular}




\begin{tabular}{|c|c|c|c|c|c|c|}
\hline & $\begin{array}{l}\text { circadian-like } \\
\text { fluctuation up to } \\
\text { 1.7-fold change } \\
\text { [95], up to } 200 \% \\
\text { increase in } \\
\text { indwelling } \\
\text { catheter studies } \\
\text { [93]; } \uparrow \text { over time } \\
\text { in younger } \\
\text { participants [92] }\end{array}$ & & & & & \\
\hline $\begin{array}{l}\text { Location and } \\
\text { volume of } \\
\text { CSF } \\
\text { sampling }\end{array}$ & $\begin{array}{c}\uparrow \text { in lumbar vs } \\
\text { ventricular in } \\
\text { NPH patients } \\
{[103]}\end{array}$ & $\begin{array}{l}\text { No significant } \\
\text { effect } \\
{[73,90,100,102]}\end{array}$ & $\begin{array}{c}\uparrow \text { concentration } \\
\text { from ventricular } \\
\text { vs lumbar } \\
\text { catheter [90]; in } \\
\text { NPH patients } \\
\text { [103] }\end{array}$ & $\begin{array}{l}\text { No significant } \\
\text { effect }[100,102]\end{array}$ & $\begin{array}{c}\uparrow \text { concentration } \\
\text { in ventricular vs } \\
\text { lumbar fraction } \\
\text { in NPH patients } \\
{[102,103]}\end{array}$ & $\begin{array}{l}\text { No significant } \\
\text { effect [100] }\end{array}$ \\
\hline
\end{tabular}




\begin{tabular}{|c|c|c|c|c|c|c|}
\hline Type of & \multicolumn{2}{|c|}{ None reported } & \multicolumn{2}{|c|}{ None reported } & \multicolumn{2}{|c|}{ None reported } \\
\hline $\begin{array}{l}\text { Collection } \\
\text { method }\end{array}$ & $\begin{array}{c}\text { Use of a } \\
\text { styrene- } \\
\text { butadiene } \\
\text { copolymer } \\
\text { manometer } \\
\text { caused sig } \\
\downarrow 4.3 \% \\
( \pm 2.4 \mathrm{SE}, \\
P=.047 ;[108])\end{array}$ & $\begin{array}{l}\text { No difference in } \\
\text { catheter type } \\
\text { [73]; no } \\
\text { difference } \\
\text { between gravity } \\
\text { drip or aspiration } \\
\text { (n = 44; [107]) }\end{array}$ & None reported & $\begin{array}{l}\text { No difference } \\
\text { between gravity } \\
\text { drip or aspiration } \\
\text { (n = 44; [107]) }\end{array}$ & None reported & $\begin{array}{l}\text { No difference } \\
\text { between gravity } \\
\text { drip or aspiration } \\
\text { (n=44; [107]) }\end{array}$ \\
\hline $\begin{array}{l}\text { Blood } \\
\text { contamination }\end{array}$ & $\begin{array}{c}\text { Plasma } \\
\text { contamination of } \\
\text { CSF/albumin } \\
\text { ratio of } 55 \downarrow\end{array}$ & $\begin{array}{c}\text { No significant } \\
\text { effect: up to } \\
5000 \text { per } \mu \mathrm{l}[73] \text {, } \\
\text { up to } 10 \%\end{array}$ & None reported & $\begin{array}{l}\text { No significant } \\
\text { effect [114] }\end{array}$ & $\begin{array}{l}\text { Blood spiked } \\
\text { samples } \\
5000 \text { per } \mu \mathrm{l}\end{array}$ & None reported \\
\hline
\end{tabular}




\begin{tabular}{|c|c|c|c|c|c|}
\hline $\begin{array}{c}\text { concentration by } \\
\text { up to } 49 \%[73] ;\end{array}$ & contamination & by haemolysed \\
blood spiked & blood [123]. No \\
samples 5000 & effect of albumin & & $\uparrow 11 \%(P<.05 ;$ \\
per $\mu \mathrm{l} \uparrow 6 \%$ & {$[113]$} & $[114])$ \\
$(P<.05 ;[114])$ & & & \\
\hline
\end{tabular}

Abbreviations: $A \beta, \beta$ amyloid; AD, Alzheimer's Disease; CSF, cerebrospinal fluid; CV, coefficient of variation; LP, lumbar puncture; $\mathrm{NPH}$, normal pressure hydrocephalus; pTau, phosphorylated tau; SE, standard error; tTau, total tau 
Table 3

The influence of CSF storage on core AD biomarker concentration

\begin{tabular}{|c|c|c|c|c|c|c|}
\hline \multirow{2}{*}{$\begin{array}{l}\text { Pre-analytical } \\
\text { variable }\end{array}$} & \multicolumn{2}{|c|}{$A \beta(1-42)$} & \multicolumn{2}{|c|}{ tTau } & \multicolumn{2}{|c|}{ pTau } \\
\hline & $\begin{array}{l}\text { Evidence of } \\
\text { influence of } \\
\text { variable }\end{array}$ & $\begin{array}{c}\text { Evidence of no } \\
\text { influence of } \\
\text { variable }\end{array}$ & $\begin{array}{l}\text { Evidence of } \\
\text { influence of } \\
\text { variable }\end{array}$ & $\begin{array}{c}\text { Evidence of no } \\
\text { influence of } \\
\text { variable }\end{array}$ & $\begin{array}{l}\text { Evidence of } \\
\text { influence of } \\
\text { variable }\end{array}$ & $\begin{array}{c}\text { Evidence of no } \\
\text { influence of } \\
\text { variable }\end{array}$ \\
\hline Tube material & $\begin{array}{c}\text { Significant } \downarrow \\
\text { polystyrene } \\
\text { storage versus } \\
\text { PP (mean 19\%, } \\
P=.002,[73], \\
\text { mean } 36 \% \downarrow \\
\text { polystyrene, } \\
\text { [118]) or } \\
\text { polystyrene }\end{array}$ & $\begin{array}{l}\text { No significant } \\
\text { difference } \\
\text { between tube } \\
\text { brands [83]; no } \\
\text { significant } \\
\text { difference } \\
\text { between PP } \\
\text { and glass [73]; } \\
\text { PP no }\end{array}$ & $\begin{array}{c}\text { Significant } \\
\text { differences from } \\
\text { different types } \\
\text { of PP tube } \\
\text { (acceptable } \\
\text { range; [117]); } \\
\text { Significant } \downarrow \text { in } \\
\text { PS compared } \\
\text { with other tubes }\end{array}$ & $\begin{array}{c}\text { No significant } \\
\text { effect [117]; No } \\
\text { significant } \\
\text { difference } \\
\text { between tube } \\
\text { brands [83] }\end{array}$ & $\begin{array}{c}\text { Significant } \\
\text { differences from } \\
\text { different types } \\
\text { of PP tube } \\
\text { (acceptable } \\
\text { range; [117] }\end{array}$ & $\begin{array}{l}\text { No significant } \\
\text { effect ; No } \\
\text { significant } \\
\text { difference } \\
\text { between tube } \\
\text { brands [83] }\end{array}$ \\
\hline
\end{tabular}




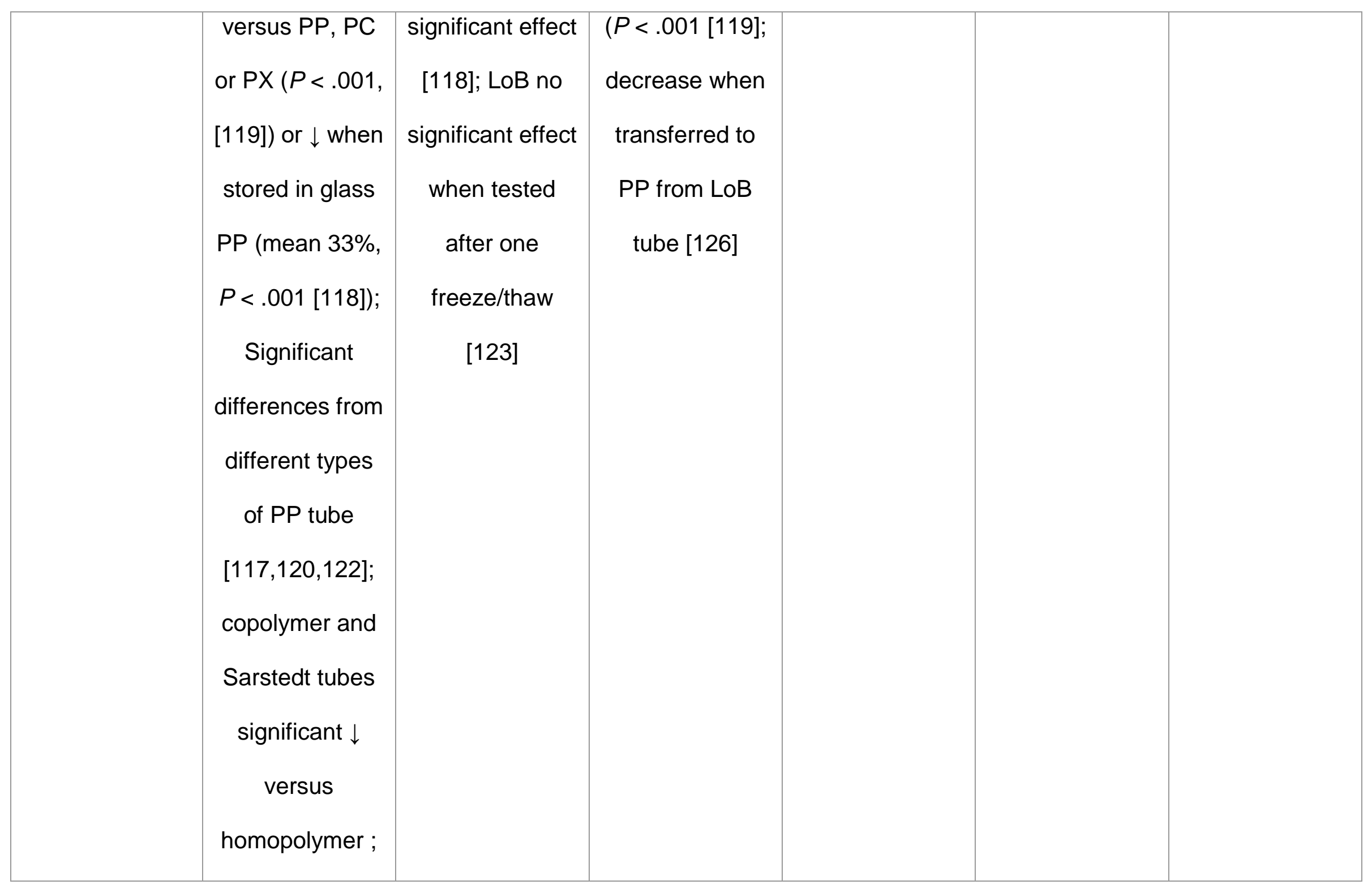




\begin{tabular}{|c|c|c|c|}
\hline much higher \\
concentration in \\
Sarstedt PP \\
{$[117] ;$} \\
Significant $\downarrow$ in \\
PP versus LoB \\
tubes (11.0\%; \\
$\begin{array}{c}\text { S124]); } \\
\text { Significant } \downarrow \text { in } \\
\text { Nunc PP } \\
\text { cryotubes } \\
\text { compared with } \\
\text { LoB [123] }\end{array} \mid$
\end{tabular} \mid




\begin{tabular}{|c|c|c|c|c|c|c|}
\hline $\begin{array}{l}\text { Aliquot tube } \\
\text { volume }\end{array}$ & $\begin{array}{l}\downarrow \text { volume from } \\
75 \text { to } 50 \%= \\
\downarrow 3.7 \%(P=.03 ; \\
[114]) ; \uparrow \text { volume } \\
\times 30=\uparrow \text { of } \sim 2- \\
\text { fold [127]; } \uparrow \\
\text { surface } \\
\text { area/volume } \\
\text { ratio }=\downarrow \text { [83], in } \\
\text { PP [124] }\end{array}$ & None reported & $\begin{array}{c}\downarrow \text { volume PP } \\
\text { tubes } 1.5 \mathrm{~mL} \text { to } \\
0.5 \mathrm{~mL}=\downarrow 4.5 \% \\
(P=.001[126])\end{array}$ & $\begin{array}{l}\text { No significant } \\
\text { effect }[114,127]\end{array}$ & None reported & $\begin{array}{l}\text { No significant } \\
\text { effect [114] }\end{array}$ \\
\hline $\begin{array}{l}\text { Temperature } \\
\text { between } \\
\text { collection and } \\
\text { analysis/storage }\end{array}$ & $\begin{array}{c}2 \text { days } \mathrm{RT} \text { or } \\
4^{\circ} \mathrm{C} \downarrow \sim 20 \% \\
\text { [130]; } 2 \text { days } \\
\text { RT } \uparrow \sim 15 \% \\
{[100] ;}\end{array}$ & $\begin{array}{l}\text { Up to } 24 \text { hours } \\
\qquad \mathrm{RT}=\text { no } \\
\text { significant effect } \\
{[73,100,128] \text {; up }} \\
\text { to } 6 \text { hours } \mathrm{RT} \text { or } \\
3 \text { days } 4^{\circ} \mathrm{C} \text { also }\end{array}$ & $\begin{array}{c}\downarrow \text { after holding } \\
\text { at }-20^{\circ} \mathrm{C} \\
\text { compared } \\
\text { with }-80^{\circ} \mathrm{C} \\
{[100] ; \text { after } \sim 12} \\
\text { days at } 37^{\circ} \mathrm{C}\end{array}$ & $\begin{array}{l}\text { No difference } \\
\text { up to } 22 \text { days at } \\
4^{\circ} \mathrm{C} \text { or } 18^{\circ} \mathrm{C} \\
\text { [130]; } 24 \text { hours } \\
\text { RT [128,134]; } 7 \\
\text { days RT [131]; }\end{array}$ & $\begin{array}{c}\downarrow \text { after freezing } \\
\text { at }-20^{\circ} \mathrm{C} \\
\text { versus }-80^{\circ} \\
(P=.001[100])\end{array}$ & $\begin{array}{c}\text { No effect } \\
24 \text { hours at RT } \\
{[128,129,134] ;} \\
\text { up to } 3 \text { days } \\
\text { [54]; } 7 \text { days RT } \\
\text { [131]; up to 5- }\end{array}$ \\
\hline
\end{tabular}




\begin{tabular}{|c|c|c|c|c|c|c|}
\hline & $\begin{array}{c}\uparrow \text { after } 24 \text { hours } \\
\text { RT [129]; } \\
\text { significant } \\
\text { changes in } \\
\text { peptide patterns } \\
\text { (mass spec) } \\
\text { after } 24 \text { hours } \\
\text { RT [135]; } \downarrow \text { after } \\
14 \text { days }-20^{\circ} \mathrm{C} \\
{[132]}\end{array}$ & $\begin{array}{l}\text { had no effect on } \\
\text { CSF mass } \\
\text { spectra [135]; } \\
7 \text { days RT } \\
\text { [131]; } 14 \text { days } \\
\text { RT or } 4^{\circ} \mathrm{C} \text { [132]; } \\
\text { up to } 5-7 \text { days } \\
\text { routine storage } \\
\text { conditions [133] }\end{array}$ & $\begin{array}{c}\text { [130]; } \downarrow \text { after } \\
14 \text { days RT } \\
\text { [132] }\end{array}$ & $\begin{array}{l}\text { no significant } \\
\text { effect } 14 \text { days } \\
\text { at }-20^{\circ} \mathrm{C} \text { or } 4^{\circ} \mathrm{C} \\
\text { [132] up to } 5-7 \\
\text { days routine } \\
\text { storage } \\
\text { conditions [133] }\end{array}$ & & $\begin{array}{c}7 \text { days routine } \\
\text { storage } \\
\text { conditions [133]; } \\
14 \text { days } \mathrm{RT} \\
4^{\circ} \mathrm{C} \text { or }-20^{\circ} \mathrm{C} \\
{[132]}\end{array}$ \\
\hline $\begin{array}{l}\text { Freeze/thaw } \\
\text { cycles }\end{array}$ & $\begin{array}{c}\text { Two cycles } \downarrow \\
\begin{array}{c}{[113] ; \downarrow 17.6 \%} \\
(P<.001 ; \\
[120]) ; \text { three } \\
\text { cycles } \downarrow \sim 30 \%\end{array}\end{array}$ & $\begin{array}{c}\text { One } \\
\text { freeze/thaw = } \\
\text { no difference } \\
{[73,120,130,153} \\
\text { ] or on mass } \\
\text { spectrometry }\end{array}$ & $\begin{array}{c}\text { Significant } \downarrow \\
>2 \text { cycles [100]; } \\
\text { significant } \downarrow \\
17 \% \geq 3 \text { cycles } \\
{[132]}\end{array}$ & $\begin{array}{c}\text { One } \\
\text { freeze/thaw = } \\
\text { no difference } \\
{[130,153] \text {; up to }} \\
\text { three [131]; up }\end{array}$ & $\begin{array}{c}\text { Significant } \downarrow \\
16 \% \geq 3 \text { cycles } \\
{[132]}\end{array}$ & $\begin{array}{c}\text { Up to three } \\
\text { [131]; up to four } \\
\text { [100]; up to five } \\
\text { [114] }\end{array}$ \\
\hline
\end{tabular}




\begin{tabular}{|c|c|c|c|c|c|c|}
\hline & $\begin{array}{c}{[136], \downarrow \sim 20 \%} \\
{[130] ;} \\
\text { four cycles } \\
\downarrow 16 \%(P<.05 ; \\
[100]) ; \text { five } \\
\text { cycles } \downarrow 5 \%(P \\
<.05 ;[114]\end{array}$ & $\begin{array}{c}\text { intensities ; up } \\
\text { to three } \\
{[100,123,131]} \\
{[132][114]}\end{array}$ & & $\begin{array}{l}\text { to five [114]; up } \\
\text { to six [130] }\end{array}$ & & \\
\hline $\begin{array}{l}\text { Storage time } \\
\left(-80^{\circ} \mathrm{C}\right)\end{array}$ & $\begin{array}{c}\uparrow \text { after } 7 \text { months } \\
{[138]}\end{array}$ & $\begin{array}{c}>3 \text { months } \\
\text { [123]; up to 1 } \\
\text { year [133,137]; } \\
2 \text { years } \\
\text { [73,131]; } \\
\text { prolonged } \\
\text { storage } \\
\text { [130,138-140]; }\end{array}$ & None reported & $\begin{array}{c}>1 \text { year }-70^{\circ} \mathrm{C} \\
\text { no effect }[134] ; \\
\text { prolonged } \\
\text { storage does } \\
\text { not have an } \\
\text { effect } \\
{[130,131,139,14} \\
0,154]\end{array}$ & None reported & $\begin{array}{c}>1 \text { year }-70^{\circ} \mathrm{C} \\
\text { no effect }[134] ; \\
\text { prolonged } \\
\text { storage does } \\
\text { not have an } \\
\text { effect } \\
{[131,140,154]}\end{array}$ \\
\hline
\end{tabular}




\begin{tabular}{|l|c|c|c|c|c|}
\hline & up to 7 months \\
{$[138]$} & & & & \\
\hline
\end{tabular}

Abbreviations: $A \beta, \beta$ amyloid; AD, Alzheimer's Disease; CSF, cerebrospinal fluid; LoB, low binding; PC, polycarbonate; PP, polypropylene; PS, polystyrene; pTau, phosphorylated tau; PX, a copolymer of polystyrene and acrylonitrile; RT, room temperature; SE, standard error; tTau, total tau. 
Table 4

The influence of CSF treatment on biomarker concentration

\begin{tabular}{|c|c|c|c|c|c|c|}
\hline \multirow{2}{*}{$\begin{array}{l}\text { Pre-analytical } \\
\text { variable }\end{array}$} & \multicolumn{2}{|c|}{$A \beta(1-42)$} & \multicolumn{2}{|c|}{ tTau } & \multicolumn{2}{|c|}{ pTau } \\
\hline & $\begin{array}{l}\text { Evidence of } \\
\text { influence of } \\
\text { variable }\end{array}$ & $\begin{array}{c}\text { Evidence of no } \\
\text { influence of } \\
\text { variable }\end{array}$ & $\begin{array}{l}\text { Evidence of } \\
\text { influence of } \\
\text { variable }\end{array}$ & $\begin{array}{c}\text { Evidence of no } \\
\text { influence of } \\
\text { variable }\end{array}$ & $\begin{array}{l}\text { Evidence of } \\
\text { influence of } \\
\text { variable }\end{array}$ & $\begin{array}{c}\text { Evidence of no } \\
\text { influence of } \\
\text { variable }\end{array}$ \\
\hline Additives & $\begin{array}{c}0.05 \% \text { Tween- } \\
20=\uparrow \text { of } \sim 29 \% \\
\text { (control and } \\
\mathrm{MCl} \text { ) to } 35.9 \% \\
(\mathrm{AD}), P<.001 \\
{[141], \uparrow \text { of } 69 \%,} \\
P<.001[142] ; \\
\uparrow\end{array}$ & $\begin{array}{c}\text { No significant } \\
\text { effect on } \\
\text { concentration of } \\
\text { up to } 0.05 \% \\
\text { Tween- } 20 \text { or } \\
\text { Triton } \mathrm{X}-100 \\
\text { [124]; no effect of } \\
0.1 \% \mathrm{NaN}_{3} \text { on }\end{array}$ & $\begin{array}{l}0.05 \% \text { Tween- } \\
\begin{array}{l}20=\uparrow \text { of } 4 \%, P \\
=.001[141]\end{array}\end{array}$ & $\begin{array}{l}\text { Any observed } \\
\text { changes not } \\
\text { significant } \\
\text { reported [142] }\end{array}$ & None reported & $\begin{array}{c}\text { Any observed } \\
\text { changes not } \\
\text { significant [141] } \\
\text { [142] }\end{array}$ \\
\hline
\end{tabular}




\begin{tabular}{|c|c|c|c|c|c|c|}
\hline & $\begin{array}{c}{[73,122,123,127} \\
, 136,138]\end{array}$ & $\begin{array}{l}\text { concentration } 5 \\
\text { days RT [133] }\end{array}$ & & & & \\
\hline $\begin{array}{l}\text { Heat } \\
\text { denaturation }\end{array}$ & $\begin{array}{c}\uparrow[73] ; \\
\text { SDS heat } \\
\text { prevented a } \downarrow \\
\text { otherwise seen } \\
\text { following } \\
\text { freezing, with } \\
\text { SDS [155] }\end{array}$ & $\begin{array}{l}\text { No significant } \\
\text { effect [113] }\end{array}$ & \multicolumn{2}{|c|}{ None reported } & \multicolumn{2}{|c|}{ None reported } \\
\hline Centrifugation & $\downarrow[73,141,143]$ & $\begin{array}{c}\text { No significant } \\
\text { effect } \\
{[100,114,130]}\end{array}$ & $\downarrow[143]$ & $\begin{array}{c}\text { No significant } \\
\text { effect } \\
{[100,114,130,14} \\
1]\end{array}$ & $\downarrow[143]$ & $\begin{array}{c}\text { No significant } \\
\text { effect } \\
{[100,114,130]}\end{array}$ \\
\hline Shaking & $\begin{array}{c}\downarrow 7 \% 48 \text { hours } \\
\text { RT } \\
(P<.05 ;[144]\end{array}$ & $\begin{array}{c}\text { No effect of } \\
\text { vortexing [83] }\end{array}$ & $\begin{array}{c}\downarrow 30 \% 48 \text { hours } \\
\text { RT } \\
(P<.001 ;[144])\end{array}$ & None reported & \multicolumn{2}{|c|}{ None reported } \\
\hline
\end{tabular}


Abbreviations: $A \beta, \beta$ amyloid; $A D$, Alzheimer's Disease; $C S F$, cerebrospinal fluid; $M C l$, mild cognitive impairment; NaN3, sodium azide; pTau, phosphorylated tau; RT, room temperature; SDS, sodium dodecyl sulphate tTau, total tau. 